\title{
Review \\ The Role of Structural Variation in Adaptation and Evolution of Yeast and Other Fungi
}

\author{
Anton Gorkovskiy ${ }^{1,2}$ and Kevin J. Verstrepen ${ }^{1,2, *}$ \\ 1 Laboratory for Genetics and Genomics, Centre of Microbial and Plant Genetics (CMPG), KU Leuven, \\ Gaston Geenslaan 1, 3001 Leuven, Belgium; anton.gorkovskiy@kuleuven.vib.be \\ 2 Laboratory for Systems Biology, VIB-KU Leuven Center for Microbiology, Bio-Incubator, \\ Gaston Geenslaan 1, 3001 Leuven, Belgium \\ * Correspondence: kevin.verstrepen@kuleuven.be; Tel.: +32-(0)16-75-1393
}

Citation: Gorkovskiy, A.; Verstrepen, K.J. The Role of Structural Variation in Adaptation and Evolution of Yeast and Other Fungi. Genes 2021, 12, 699. https://doi.org/10.3390/ genes12050699

Academic Editor: Manuel

A. Garrido-Ramos

Received: 14 April 2021

Accepted: 4 May 2021

Published: 8 May 2021

Publisher's Note: MDPI stays neutral with regard to jurisdictional claims in published maps and institutional affiliations.

Copyright: (c) 2021 by the authors. Licensee MDPI, Basel, Switzerland. This article is an open access article distributed under the terms and conditions of the Creative Commons Attribution (CC BY) license (https:// creativecommons.org/licenses/by/ $4.0 /)$.

\begin{abstract}
Mutations in DNA can be limited to one or a few nucleotides, or encompass larger deletions, insertions, duplications, inversions and translocations that span long stretches of DNA or even full chromosomes. These so-called structural variations (SVs) can alter the gene copy number, modify open reading frames, change regulatory sequences or chromatin structure and thus result in major phenotypic changes. As some of the best-known examples of SV are linked to severe genetic disorders, this type of mutation has traditionally been regarded as negative and of little importance for adaptive evolution. However, the advent of genomic technologies uncovered the ubiquity of SVs even in healthy organisms. Moreover, experimental evolution studies suggest that SV is an important driver of evolution and adaptation to new environments. Here, we provide an overview of the causes and consequences of SV and their role in adaptation, with specific emphasis on fungi since these have proven to be excellent models to study SV.
\end{abstract}

Keywords: structural variation; fungi; adaptation

\section{Introduction}

Structural variation (SV) groups different forms of mutations that involve longer stretches of DNA, including deletions, insertions, duplications, inversions, translocations, or even full chromosome fusion, fission or loss (Figure 1). Structural variants can be balanced and show no specific loss or gain of DNA information, such as inversions of a genetic fragment or translocations of a stretch of DNA within or between chromosomes, or they can be unbalanced, where a part of the genome is lost (deletions), acquired (insertions) or duplicated (duplications), which is termed copy number variation (CNV).

Structural variation may occur both in coding and noncoding regions of the genome, including in highly repetitive elements, such as transposons. SV events can lead to major phenotypic changes via diverse mechanisms including modification of open reading frames, changes in gene expression due to copy number variation, alteration of regulatory sequences (via gain or loss of functional genomic elements) or chromatin structure, or even formation of novel genes [1-5]. Moreover, some forms of SV, such as large inversions and chromosomal fusions, cause a reduction in recombination rates between homologous chromosome pairs. In turn, the reduced recombination may facilitate the cosegregation of multiple adaptive polymorphisms as if they were controlled by a single genetic locus (linkage disequilibrium and supergene formation) [6-11].

In humans, single nucleotide variants (SNVs) are the most common type of variation, but SV accounts for a higher number of variable nucleotides between genomes, with roughly $0.5 \%$ of the human genome being involved in structural variation [12,13]. Strikingly, third-generation (long-read) genome sequencing of a clonal population of seven closely related Schizosaccharomyces pombe strains that diverged $\sim 50-65$ years ago revealed that they have an average pairwise difference of 19 SNVs and four nonoverlapping larger 
duplications [14]. Moreover, SVs are three times more likely to be associated with a genome-wide association signal and 50 times more likely to be associated with expressed quantitative trait loci than single nucleotide variants, further hinting at their importance as drivers of phenotypic variation $[13,15]$. Importantly, despite the significant contribution of SV events (especially of CNVs) to quantitative traits, they are frequently overlooked in studies employing short-read sequencing technologies [14].

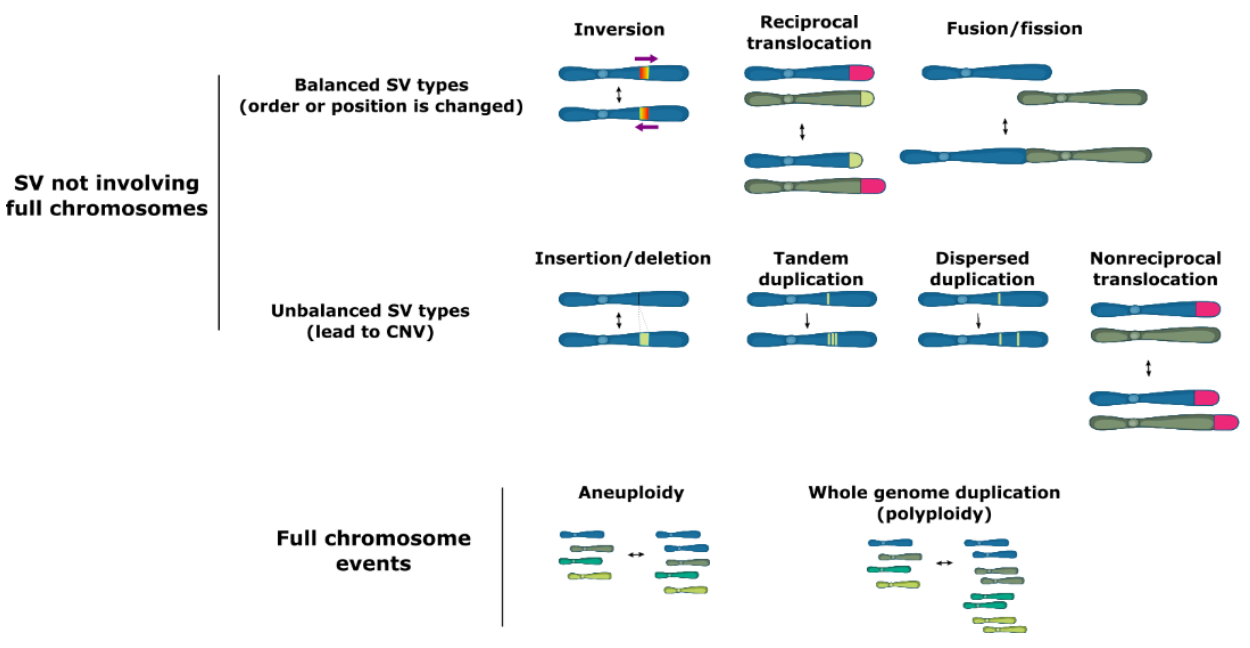

Figure 1. Types of structural variation.

The phenotypic consequences of SVs have traditionally been assumed to be almost exclusively negative. This is perhaps partly due to the association of SVs with many human diseases, especially autoimmune, metabolic, and cognitive disorders [16-20]. However, the emergence of advanced genotype-to-phenotype mapping technologies, as well as studies focusing on experimental evolution have led to a growing body of evidence suggesting that many SVs are neutral or even adaptive, both in humans $[12,15,21]$ and other organisms, including microbes [11,22-31]. SVs are therefore increasingly considered to be an important evolutionary driver, and some studies suggest that SV may be especially important for quick adaptation.

In this paper, we summarize recent advances in the detection and analysis of SV and the emerging insight into their adaptive role with the focus on yeasts and other fungi, which have served as prime models for many studies focusing on SV.

\section{Mechanisms of SV Formation}

SV involving complete chromosomes is often caused by defective chromosome segregation. Chromosomes must be meticulously replicated and equally segregated at each cell division. Distortion of either one of these processes can lead to SV formation. In particular, failure of any of the critical chromosome segregation steps, including chromatid cohesion, spindle pole body (functional equivalent of the mammalian centrosome) formation at opposite cell poles, kinetochore-microtubule attachment, and quality control at the spindle assembly checkpoint can result in aneuploidy (i.e., loss or gain of whole chromosomes) (Figure 2A) [32].

An SV that does not involve full chromosomes often results from compromised DNA replication, where processive forks collide with the replication fork barriers (Figure 2B) [33-35]. These barriers typically include (1) specific DNA secondary structures such as G-quadruplex (G4) motifs [36-38], which are enriched in the telomeres, ribosomal DNA (rDNA) and promoter regions in S. cerevisiae, Schizosaccharomyces pombe, and human cells [39-44]; (2) highly expressed loci such as the tRNA genes where transcription can interfere with replication [45-47]; or (3) tightly DNA bound nonhistone proteins (e.g., at centromeres) $[48,49]$. Replication forks can also be stalled as a result of DNA damage or the inhibition of replication by nucleotide depletion [50,51]. Reactivation of blocked replication 
forks and DNA damage can lead to SV due to the occurrence of nonallelic homologous recombination resulting from incorrect repair template utilization (Figure 2C) [52-54]. This process is remarkably more frequent in the case of dispersed repetitive DNA sequences such as transposable elements or remnants of those (long terminal repeats), tRNA genes, origins of replication, and clusters of tandemly repeated genes including those encoding ribosomal RNA and those residing in subtelomeric duplication blocks [14,54-67]. Curiously, stretches of repetitive DNA and, in particular, transposable elements are enriched in highly fast-evolving genomic compartments (which exist as 'islands' on core chromosomes) and accessory chromosomes of many pathogenic filamentous fungi [68-74]. These genomic compartments were shown to be the hot spots of SV [73,74]. Increased plasticity of the indicated genomic regions known to bear the virulence-related genes likely allows pathogens to keep up with the evolution of the host defense mechanisms and succeed in pathogen-host "arms race".
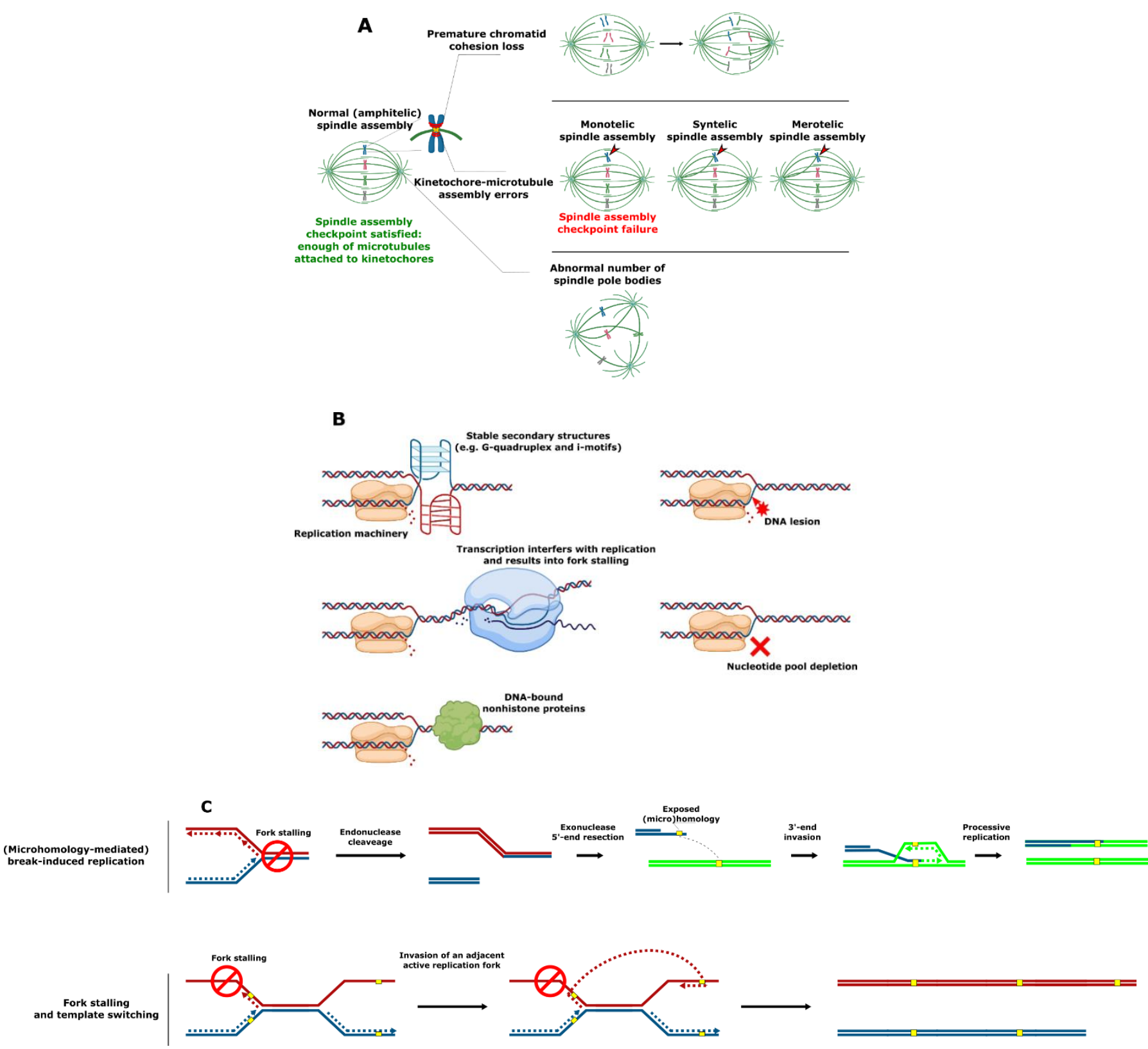

Figure 1. Cont. 
D
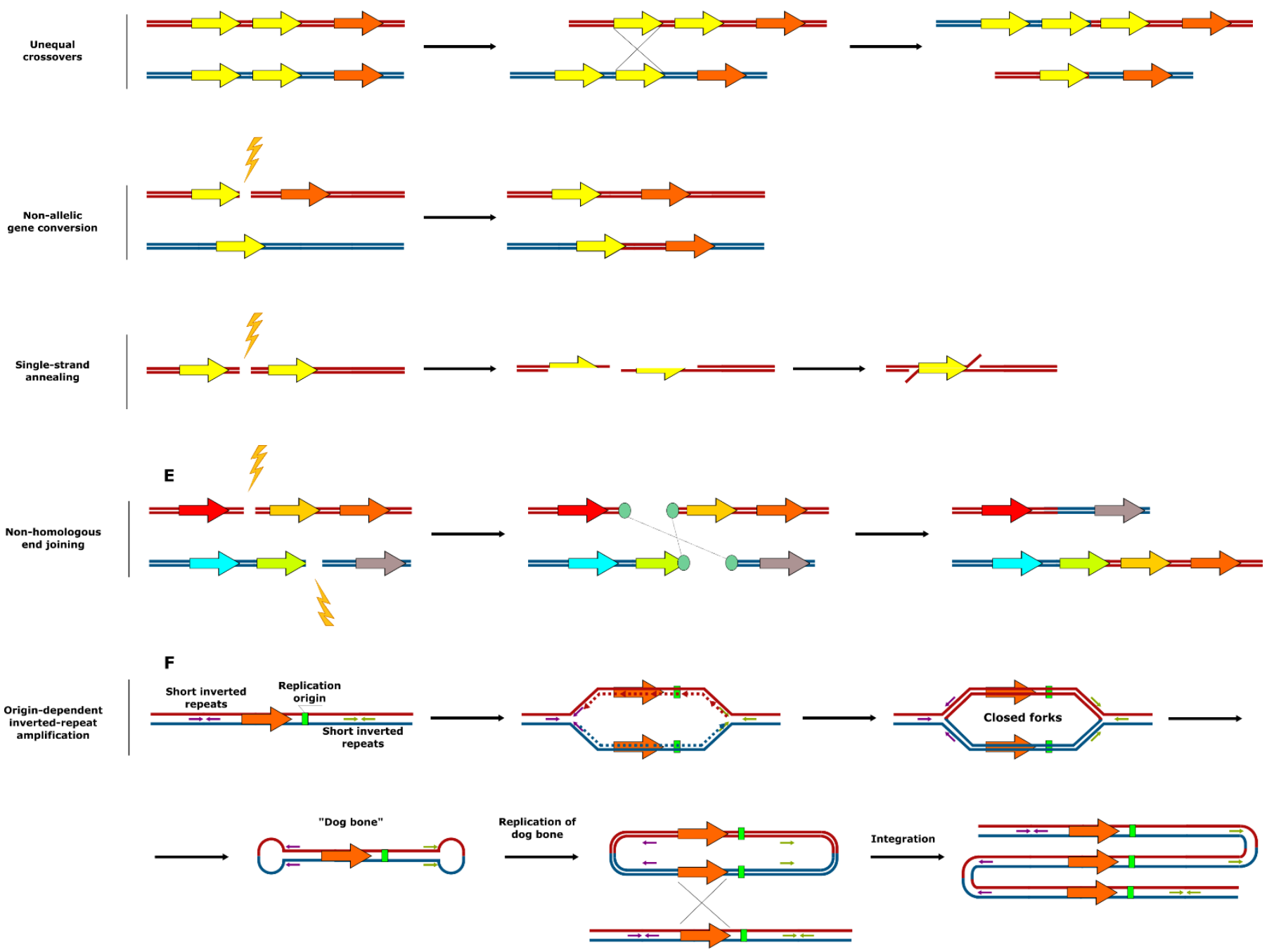

Figure 2. Mechanisms of SV formation. (A) Events leading to aneuploidy. (B) Events leading to replication fork collapse. (C) SV formation as a result of stalled replication fork reactivation. (D) SV formation mediated by homologous recombination.

(E) SV formation mediated by nonhomologous end joining. (F) Origin-dependent inverted-repeat amplification.

A third major mechanism underlying SV is linked to crossing-over between repetitive DNA sequences and the repair of DNA double strand breaks near repetitive DNA sequences (Figure 2D,E) [75,76]. Various types of homologous recombination at repeat sites, including unequal crossovers, gene conversion, and single-strand annealing were reported to result in CNV [75]. A specific example of repeat-associated CNV generation, origin-dependent inverted-repeat amplification (Figure 2F), was hypothesized to underlie the amplification of the SUL1 locus in yeast $[77,78]$. As a result of the DNA replication error at small, interrupted inverted repeats, nascent leading and lagging strands get covalently linked. This ends up in formation of an extrachromosomal circular intermediate, and its integration into original chromosomal locus results in the gene triplication [77,78]. In some specific cases, copy number amplification is achieved via the formation of the extrachromosomal circular elements [79], which were proposed to be a fast and revocable mechanism of gene copy number amplification $[80,81]$.

Finally, a very specific source of gene duplications is the whole genome duplication (WGD, also referred to as polyploidization) - i.e., addition of a complete set of chromosomes to the genome $[82,83]$. 


\section{Gene Duplications: Fruitful Soil for Evolution and Adaptation}

The types of SV resulting in a net gain of genetic material such as gene, chromosome segment, full chromosome duplications, as well as WGD events are currently recognized as major sources of adaptation and even evolutionary innovation. Susumo Ohno famously hypothesized that apart from causing differences in gene dosage, gene duplications may create substrates for evolutionary diversity and innovation, including the development of new genes [84,85]. Recent studies focusing on domesticated and experimentally evolved microbes [31,86-93] as well as domesticated higher organisms [94,95] seem to confirm that $\mathrm{SV}$ occurs frequently and can in some cases be adaptive.

The ancestor of the common beer and wine yeast, S. cerevisiae, duplicated its genome roughly 100 MYA presumably as a consequence of interspecies hybridization [96]. This whole genome duplication allowed the initially sterile hybrid to restore fertility [97-99]. Whereas the $S$. cerevisiae genome contains roughly 5000 genes, the current genome only contains 1120 pairs of duplicates, approximately half of which belong to the WGD event (so-called "ohnologs") and the remaining are classified as small-scale duplications [100,101]. Thus, the vast majority of genes that were duplicated during the whole genome duplication event eventually returned back to the original copy number [96]. The predominant re-establishment of the original copy number agrees well with Ohno's classic theory according to which one of the gene copies remains under strong purifying selection while another copy explores novel genotypes, many of which turn out to be detrimental to the organism and are eventually lost $[85,102,103]$. Both gene copies can be preserved if the resulting increased activity of genes preserving the ancestral function confers an immediate selective benefit (gene dosage effect) [104]. Duplicated genes can also be preserved when they encode different components of a multisubunit protein complex, so that loss of one of the duplicated alleles would cause a stoichiometric imbalance [105-107]. In case of multifunctional ancestral genes, subfunctionalization, i.e., the split of the functions between the different gene copies, can drive the conservation of both ohnologs [85,102,103,108-111]. Lastly, duplicated genes can also be preserved when one copy evolves a novel, beneficial function (neofunctionalization) or a novel expression pattern [112-115]. Indeed, duplicates were demonstrated to be more transcriptionally polymorphic than singleton genes [116]. Moreover, the fraction of the genes upregulated in stress conditions is significantly higher among ohnologs than among singleton genes in S. cerevisiae, suggesting that gene duplication underlies the adaptation to environmental stress [115].

Importantly, these different mechanisms that drive the retention of gene duplicates are not mutually exclusive. For instance, dosage constraints were proposed to allow genes to be retained for long enough before changes of function occur $[108,117]$. Case-by-case variation in the contribution of each particular mechanism is expected.

\section{Whole Genome Duplication}

Whereas WGD is often considered to be an evolutionary dead end [118], there are many cases of currently polyploid plants, insects, fishes, amphibians, reptiles [119-123] and fungi (reviewed in [124]) which suggests that WGD plays a role in adaptation [125]. Application of the advanced phylogenetic dating methods demonstrated that establishment of polyploids may be promoted during times of environmental cataclysms [118]. In fact, as more and more genomes are sequenced, it becomes increasingly clear that most present-day eukaryotic taxa descended from lineages in which one or multiple WGD events occurred at some point during their evolution [126-129], including at least two WGDs in the vertebrate lineage [130], and one in S. cerevisiae [96,131].

WGD is traditionally classified as either autoduplication or alloduplication depending on whether the doubling of one chromosome set happened within a single species or through the merging of the chromosome sets of different species (hybridization) and subsequent doubling [118]. WGD formation mechanisms include endoreduplication resulting from cytokinesis failure [132] and the loss of function of one copy of the mating-type locus in the hybrid $[133,134]$. The ancient WGD in the Saccharomyces lineage is thought to be a 
result of alloduplication, involving loss of heterozygosity at the mating-type locus, thereby restoring fertility $[97,98]$. Both autoduplication and, especially, alloduplication followed by extensive SV events (between and inside of the parental subgenomes) seem to be the major source of genetic diversity and, thus, the propellant of evolution and adaptation in fungi (reviewed in [135]).

The results of various experimental evolution studies in yeast show that the duplication of the genome is a frequent first step towards adaptation. In fact, invasion and subsequent fixation of autodiploids was found to be a common theme in evolving S. cerevisiae lineages that started from haploid founder populations $[26,93,136-140]$. A recent study in S. cerevisiae found autodiploids to occur in haploid cultures at a rate on the order of $10^{-5}$ per cell division [141], similar to that in flowering plants [142], which is much higher than the mutation rates per cell division per base pair of $1.1 \times 10^{-10}$ to $4 \times 10^{-10}$ for haploids $[67,143,144]$ and $1 \times 10^{-10}$ to $3 \times 10^{-10}$ for diploids $[143,145-147]$. Such relatively high WGD rate explains the widely encountered autodiploid invasion in haploid-founded evolution experiments. Consistent with these observations and in accordance with the presumed adaptive potential of WGDs, recent analysis of $>1000$ yeast genomes revealed that the majority $(87 \%)$ of natural isolates are diploids, while polyploids $(3-5 \mathrm{n})$ are also frequently encountered, especially in specific human-related niches [148]. This can be attributed to the direct fitness advantage conferred by WGD (3.6\% fitness benefit in some environments [26]), possibly stemming from the larger cell size of diploid cells [149-151] that may facilitate increased growth rates. Moreover, autodiploids were demonstrated to resort to adaptive strategies (in terms of utilized types of mutations) inaccessible to haploids [26]. In particular, aneuploidies and other structural variants accumulate at a significantly higher rate in autodiploids than in haploids, presumably due to buffering of lethal and deleterious recessive mutations [26,143,152-157]. For example, Fisher et al. demonstrated that all 46 haploid-founded populations traced in their study converged into diploids by generation 1000. Among these 46 populations, six independently evolved aneuploidies and 20 independently evolved various structural variants [26]. Notably, the spectrum of structural variants generally differs between evolved haploids and diploids. Autodiploid structural variants include both amplifications and (large) deletions, while haploid ones normally result in a net gain of genetic material [143].

Whereas diploids are generally more fit than haploids, (fresh artificially created) strains with ploidy $>2 n$ tend to be less fit than diploids at least in some growth conditions $[158,159]$. Additionally, polyploids occur less often in nature compared to diploids [148]. This "ploidy threshold" [160] may at least be partly due to altered geometric relationships between the surface area of the spindle pole body and the length of the preanaphase mitotic spindle, resulting in altered mitotic spindle structure and thus hampered chromosome segregation $[159,160]$. This agrees with high levels of chromosome loss and interhomolog recombination observed in tetraploid yeasts [161-164]. Extended propagation of triploid and tetraploid yeasts often results in a gradual loss of chromosomes (aneuploidy) and, eventually, convergence to (near-) diploid state [64,93,140,165]. Moreover, deletion of genes important for accurate chromosome segregation is lethal for tetraploids but not for haploids and diploids, suggesting that proper chromosome segregation is challenging in polyploids $[159,166]$. However, the increased instability of polyploid genomes may also offer advantages in terms of evolutionary plasticity. Indeed, tetraploids have been shown to boast higher rates of adaptation and higher frequencies and greater diversity of mutations than isogenic haploid and diploid yeast strains that evolved in an environment with a poor carbon source $[64,165]$. Interestingly, chromosome aneuploidies and/or concerted loss of pairs of chromosomes was observed in 26 out of 28 evolved tetraploid strains at generation 250 , suggesting that structural variation could be at the basis of the better adaptation observed in polyploids [64]. 


\section{Aneuploidy and Segmental Duplications: A “Quick Fix" for Evolutionary Adaptation?}

Aneuploidy is a special form of SV that occurs surprisingly frequently in fungi. Aneuploidy has traditionally been considered as detrimental, in part because in most higher eukaryotes it results in sickness or, more frequently, death. There are multiple reasons why aneuploidy may affect an organism's fitness, the most obvious one being its effect on gene expression. Doubling the copy number of single chromosomes leads to increased expression of nearly all of the genes on that chromosome, resulting in disproportionate expression of genes residing on different chromosomes [167]. This could be especially harmful for genes encoding subunits of the same protein complex and can result in protein misfolding and aggregation and thus proteotoxic stress. In addition, aneuploidy has also been associated with increased mutation rates, especially on the duplicated chromosome(s), and chromosome mis-segregation [168-174]. Moreover, overabundant protein subunits increase intracellular solute concentration, resulting in high cytoplasmic osmolarity in aneuploid cells. As a result, the aneuploidy-associated transcriptome signature common for aneuploid cells with random karyotypes closely resembles that of cells experiencing osmotic stress [175]. In the S. cerevisiae laboratory strain W303, aneuploidy also leads to severe growth defects, metabolic dysfunction, transcriptome changes and cell-cycle defects $[167,169,176-181]$.

Despite the multitude of studies that report the detrimental effects of aneuploidy, many yeast strains coming from diverse ecological niches, including many clinical isolates and industrial strains, are aneuploid [86,182-189]. It was demonstrated that $19.1 \%$ of natural S. cerevisiae isolates contain chromosome aneuploidies and instances of large segmental duplications, especially for chromosomes I, III and IX [148]. Interestingly, only mild growth reduction was observed in natural aneuploid S. cerevisiae yeast strains compared to (artificially generated) isogenic euploid counterparts, and there did not seem to be clear evidence of metabolic or proteotoxic stress in tested growth conditions (on media having glucose, ethanol, glycerol, and acetate as a carbon source) $[182,190]$. The difference in the tolerance for aneuploidy between the highly intolerant S. cerevisiae strain W303 and more tolerant wild strains was recently mapped to the RNA-binding translational regulator Ssd1, which is defective in W303 [191]. Ssd1 is involved in regulating where, when, and to which extent mRNAs are translated, which is essential for enabling the cells to minimize protein aggregation and misfolding and, thus, to cope with the burden imposed by extra chromosomes. Consistently, in another laboratory strain, S288C, bearing a full-length copy of the SSD1 gene, aneuploidy was shown not to result in proteotoxic stress [192].

More generally, the results of the recent study of over 1000 published S. cerevisiae genomes suggest that genetic background influences variation in aneuploidy frequency and cellular tolerance of aneuploidy stress [193]. It is likely that aneuploidies are near-neutral in many strains and, once they appear, may persist in the population [193]. Furthermore, it is more and more evident that aneuploidy can actually also be beneficial for adaptation, especially when gene expression issues are resolved [67]. Indeed, aneuploidies were shown to drive the adaptation to different types of environmental stress, including limiting nutrients, high ethanol concentration, heat shock, oxidative stress, endoplasmic reticulum stress, and drug resistance [31,92,93,155,194-201]. In addition, aneuploidy has been shown to help suppress certain genetic mutations such as telomerase insufficiency [202,203], cytokinesis perturbation [91], disruption of essential nucleoporin genes [204] and loss of a small ubiquitin-related modifier protease [205]. In many cases, the selective advantage can be attributed to copy number changes of a few genes on the aneuploid chromosomes $[91,196,199,205,206]$. In addition, several studies indicate that aneuploidy leads to increased spontaneous mutation rates $[67,168,173]$, which may of course also result in beneficial mutations that can drive adaptation. Interestingly, fixed mutations in disomic lines are frequently located on the duplicated chromosomes, likely due to relaxed purifying selection on the duplicated genes [31,67].

Aneuploidies appear in S. cerevisiae diploid cells with a frequency close to that of WGD events $\left(10^{-5}\right.$ to $3 \times 10^{-4}$ per cell division); generally, chromosome gains prevail over 
the chromosome losses $[143,146,207]$. As mentioned above, the frequency of aneuploidy is further increased in cells with $>2 n$ ploidy [64].

Whereas aneuploidy can help improve fitness by changing the expression of certain genes, the possible advantage is often upset by the general disadvantage of expression imbalances for many other genes. Hence, aneuploidy is often not a very stable state, with subsequent genomic rearrangements gradually reducing the negative effects. The cellular response to aneuploidy has been analyzed at both the transcriptome and proteome levels in S. cerevisiae $[67,90,175,179]$. In disomic strains, the aneuploidy response involves loss of parts of the duplicated chromosomes, with a clear tendency towards euploidy restoration. In addition to reducing the copy number of certain duplicated segments, the opposite has also been observed. Segmental duplication of nondisomic chromosomes was observed in response to duplication of chromosomes XII and XIV, which could balance out the overexpression of the (particular) genes on the disomic chromosomes [67]. This is in line with the results of Ravichandran et al., who observed that yeast stains engineered to have high rate of chromosomal mis-segregation due to BIR1 deletion, in time restored their fitness via acquisition of complex karyotypes that consisted of specific subsets of the beneficial aneuploid chromosomes [174]. The "optimal" aneuploid karyotypes shaped via the gain and loss of chromosomes were dictated by genetic interactions between aneuploid chromosomes. For instance, in diploids, loss of chromosome IX strongly correlated with the gain of chromosomes $\mathrm{X}$ or XIII, while in haploids a significant negative correlation between the gain of chromosomes VIII and $X$ was observed [174].

Interestingly, the stress caused by aneuploidy is not only resolved by further changes in the copy number of certain genomic segments, but can also be mitigated by compensatory mutations. For example, in S. cerevisiae, aneuploidy may select mutations in the SCH9 kinase gene. These mutations may reduce $\mathrm{SCH} 9$-mediated ribosome biogenesis and thus decrease translation initiation, which may help in reducing the proteotoxic stress associated with an increased gene copy number [67]. Similarly, variation in SCH9 has also been implicated in the stabilization of tetraploidy [158].

Aneuploidy is often hypothesized to be a resourceful adaptive mechanism that allows a "quick fix" solution to immediate threats by changing the expression of certain key genes. While this may also bring undesirable changes in the expression of other genes, it may allow cells to quickly adapt to the stress, after which mutations and additional SVs may result in a gradual further tuning of the genome $[157,208,209]$. Hence, aneuploidy may be able to fuel fast phenotypic evolution and allow cell populations to rapidly explore adaptive mechanisms, eventually leading to large fitness gains $[64,210]$.

Akin to aneuploidy, other types of unbalanced SV events, such as segmental duplications and deletions, may also allow fast adaptation to new environments, stress, deleterious mutations or adaptive mutations that have trade-offs. In S. cerevisiae, the estimates of the frequency of such events differ drastically, ranging from $1 \times 10^{-10}$ to $1 \times 10^{-4}$ duplications per cell per division, suggesting that the rates may depend on the genomic context of the locus of interest (e.g., the existence of direct repeats flanking the locus, the distance between the repeats, the sequence similarity between the repeats), ploidy level, growth conditions and the genetic background of the organism, which may affect its ability to tolerate the CNV event [211-215]. Indeed, segmental duplications and deletions are not evenly distributed across the yeast genome. Eukaryotic subtelomeres are known hot spots of these events [216-219]. According to the results of the recent genomic study of industrial S. cerevisiae strains, the subtelomeric regions of chromosomes, defined as gene-depleted regions adjacent to telomeres $[220,221]$, are on average four times more frequently affected by $\mathrm{CNV}$ events compared to nonsubtelomeric regions, with most variability detected in subtelomeres of chromosomes I, VII, VIII, IX, X, XII, and XVI [86]. In another study, alternative definition of subtelomeres on the basis of the sudden loss of synteny conservation was proposed [65]. Analysis of long-read genome assemblies of S. cerevisiae S288C standard laboratory strain showed that most previously described duplication blocks are located in subtelomeres [65]. Since many subtelomeric genes are known to mediate the interaction 
of yeast with the environment, including functions such as stress response, nutrient uptake and ion transport $[87,221,222]$, it was hypothesized that the accelerated evolution of subtelomeric regions echoes the selection for evolvability-i.e., the ability to respond and adapt to changing environments $[65,223]$.

\section{Balanced SV Events}

Balanced SV types such as reciprocal translocations and inversions are widespread in Saccharomyces species and other fungi $[14,60,63,65,71,72,224-229]$. They are thought to serve as initial genetic barriers in eukaryotic speciation and, thus, to contribute to the onset of reproductive isolation and speciation [230-236]. In flies [237], mosquitoes [238], and flowering plants [8], inversions are hypothesized to also play a role in evolutionary adaptation. Analysis of the outcomes of chromosomal translocations in S. cerevisiae [239] and of translocations and inversions in S. pombe $[225,240]$ demonstrated that these types of SV can significantly influence the fitness of the organism in specific environments, possibly as some events cause changes in gene expression [225]. It was hypothesized that balanced types of SV can be maintained as polymorphisms in nature despite their meiotic costs (low viability in heterozygotic crosses) when this disadvantage is outweighed by the fitness advantage gained in mitosis (antagonistic pleiotropy) [225]. Contrastingly, Naseeb and colleagues were not able to detect phenotypic consequences of a set of large inversions, even if they did observe significant changes in gene transcription patterns [241]. This again underscores that the effect of a specific structural rearrangement always depends on the affected genetic locus, the genetic background and the environment.

\section{Examples of Adaptive SV Events}

As the number of sequenced genomes and experimental evolution studies is growing, there is an increasing number of examples of evolutionary adaptation driven by SV events (Table 1). In a subset of cases, the particular gene or genes underlying the adaptation have been revealed. In most cases, gene dosage of these genes played a major role, which agrees with the fact that SV events detected in S. cerevisiae are predominantly unbalanced events, such as insertions, deletions and duplications [65]. Among the genes that are gained by S. cerevisiae after the WGD event, many have functions associated with ethanol production, growth in hypoxic environments or the uptake of alternative nutrient sources $[63,242,243]$. The increased copy number of glycolytic genes and glucose transporters originating from WGD is thought be responsible for the boosting of the glycolytic flux and allow the adaptation to niches with high levels of sugars, including fruits and industrial media $[100,244,245]$. $\mathrm{CNVs}$ of nutrient transporter genes were also repeatedly detected in strains evolved to adapt to various nutrient-restricted conditions such as glucose limitation (high-affinity glucose transporters HXT6 and HXT7) [31,246], sulfate limitation (high-affinity sulfate transporter SUL1) [30,196], media containing poor nitrogen sources such as glutamine or glutamate (general amino acid permease GAP1) [79,247], allantoin (permease DAL4) or urea (permease DUR3) [139]. Interestingly, different classes of CNVs, including aneuploidies, nonreciprocal translocations, tandem duplications, and complex CNVs, that contain the general amino acid permease GAP1 were shown to be repeatedly generated and selected upon growth in nitrogen-limiting conditions [247]. Interestingly, in addition to affecting copy numbers, nonreciprocal translocations were also shown to result in increased expression levels of genes located near the CNV breakpoints, presumably due to a more open state of their chromatin structures, allowing easier access of the DNA by the transcription machinery [248]. 
Table 1. Examples of adaptive SV events.

\begin{tabular}{|c|c|c|c|c|}
\hline Phenotype & Gene(s) & Type of SV & Organism & References \\
\hline \multicolumn{5}{|l|}{ Adaptation to: } \\
\hline Glucose limitation & HXT6 and HXT7 & $\begin{array}{l}\text { Increased copy } \\
\text { number }\end{array}$ & S. cerevisiae & {$[31,246]$} \\
\hline Sulfate limitation & SUL1 & $\begin{array}{l}\text { Increased copy } \\
\text { number }\end{array}$ & S. cerevisiae & {$[30,196]$} \\
\hline $\begin{array}{l}\text { Poor nitrogen } \\
\text { sources (glutamine } \\
\text { or glutamate) }\end{array}$ & GAP1 & $\begin{array}{c}\text { Aneuploidies, } \\
\text { nonreciprocal } \\
\text { translocations, } \\
\text { tandem } \\
\text { duplication, } \\
\text { complex CNVs }\end{array}$ & S. cerevisiae & {$[79,247]$} \\
\hline $\begin{array}{c}\text { Poor nitrogen } \\
\text { sources (allantoin) }\end{array}$ & $D A L 4$ & $\begin{array}{c}\text { Increased copy } \\
\text { number }\end{array}$ & S. cerevisiae & [139] \\
\hline $\begin{array}{l}\text { Poor nitrogen } \\
\text { sources (urea) }\end{array}$ & DUR3 & $\begin{array}{c}\text { Increased copy } \\
\text { number }\end{array}$ & S. cerevisiae & [139] \\
\hline $\begin{array}{l}\text { Poor carbon sources } \\
\quad \text { (raffinose })^{1}\end{array}$ & & $\begin{array}{c}\text { Chr XIII } \\
\text { duplication }\end{array}$ & S. cerevisiae & {$[64]$} \\
\hline $\begin{array}{l}\text { Poor carbon sources } \\
\text { (L-sorbose })\end{array}$ & SOU1 & $\begin{array}{c}\text { Chr V } \\
\text { monosomy }\end{array}$ & C. albicans & [249] \\
\hline $\begin{array}{l}\text { High temperature } \\
\qquad\left(40{ }^{\circ} \mathrm{C}\right)\end{array}$ & $\begin{array}{c}\text { PAU5 and } \\
\text { several genes } \\
\text { introgressed } \\
\text { from } S . \\
\text { paradoxus }\end{array}$ & $\begin{array}{c}\text { Increased copy } \\
\text { number }\end{array}$ & S. cerevisiae & [148] \\
\hline $\begin{array}{c}\text { Elevated } \\
\text { concentration of } \\
\text { copper sulfate }\end{array}$ & $\begin{array}{c}\text { CUP1, CUP2, } \\
\text { SCO1, and SCO2 }\end{array}$ & $\begin{array}{l}\text { Increased copy } \\
\text { number }\end{array}$ & S. cerevisiae & {$[65,148,250-252]$} \\
\hline $\begin{array}{c}\text { Elevated } \\
\text { concentration of } \\
\text { sodium chloride }\end{array}$ & $\begin{array}{c}\text { ENA5, MDM36, } \\
\text { and VAR1589 } \\
\text { introgressed } \\
\text { from } S . \\
\text { paradoxus }\end{array}$ & $\begin{array}{c}\text { Increased copy } \\
\text { number }\end{array}$ & S. cerevisiae & [148] \\
\hline $\begin{array}{c}\text { Elevated } \\
\text { concentration of } \\
\text { lithium chloride }\end{array}$ & $\begin{array}{l}\text { ENA5 and } \\
\text { VAR1589 }\end{array}$ & $\begin{array}{c}\text { Increased copy } \\
\text { number }\end{array}$ & S. cerevisiae & [148] \\
\hline $\begin{array}{l}\text { Sodium } \\
\text { meta-arsenite }\end{array}$ & $\begin{array}{c}\text { Chr XVI } \\
\text { subtelomeric } \\
\text { region } \\
\text { containing } \\
A R R 1, A R R 2, \\
\text { and } A R R 3 \text { genes } \\
\text { Two genes }\end{array}$ & $\begin{array}{c}\text { Increased copy } \\
\text { number }\end{array}$ & S. cerevisiae & {$[65,148]$} \\
\hline $\begin{array}{l}\text { Nonpreferred carbon } \\
\text { sources (galactose) }\end{array}$ & $\begin{array}{l}\text { introgressed } \\
\text { from } S . \\
\text { paradoxus }\end{array}$ & $\begin{array}{c}\text { Increased copy } \\
\text { number }\end{array}$ & S. cerevisiae & [148] \\
\hline Freeze-thaw cycles & AQY2 & $\begin{array}{l}\text { Increased copy } \\
\text { number }\end{array}$ & $\begin{array}{l}\text { S. cerevisiae } S . \\
\text { paradoxus }\end{array}$ & {$[182,253]$} \\
\hline $\begin{array}{l}\text { High temperature } \\
\left(39^{\circ} \mathrm{C}\right)\end{array}$ & $\begin{array}{c}\text { HCM1, } \\
\text { YCR016W, } \\
\text { RRT12, } \\
\text { YCR102C, and } \\
\text { IMG2 }\end{array}$ & $\begin{array}{l}\text { Increased copy } \\
\text { number }\end{array}$ & S. cerevisiae & [195] \\
\hline $\begin{array}{l}\text { High temperature } \\
\left(42{ }^{\circ} \mathrm{C}\right)\end{array}$ & & $\begin{array}{c}\text { Chr III } \\
\text { segmental } \\
\text { duplication and } \\
\text { aneuploidy }\end{array}$ & S. cerevisiae & {$[254,255]$} \\
\hline $\begin{array}{l}\text { High ethanol } \\
\text { concentration }\end{array}$ & & $\begin{array}{l}\text { Chr III and Chr } \\
\text { XII duplication }\end{array}$ & S. cerevisiae & {$[93,256]$} \\
\hline
\end{tabular}


Table 1. Cont.

\begin{tabular}{|c|c|c|c|c|}
\hline Phenotype & Gene(s) & Type of SV & Organism & References \\
\hline Sulfite & SSU1 & $\begin{array}{l}\text { Translocations } \\
\text { VIII-t-XVI } \\
\text { XV-t-XVI }\end{array}$ & S. cerevisiae & {$[29,257-260]$} \\
\hline Sulfite & SSU1 & $\begin{array}{c}\text { Inversion in } \mathrm{Chr} \\
\text { XVI }\end{array}$ & S. cerevisiae & [261] \\
\hline Nystatin & $\begin{array}{l}\text { ADH4 and } \\
\text { HXK2 }\end{array}$ & $\begin{array}{l}\text { Increased copy } \\
\text { number }\end{array}$ & S. cerevisiae & [148] \\
\hline Fluconazole & ERG11 & $\begin{array}{l}\text { Increased copy } \\
\text { number }\end{array}$ & $\begin{array}{l}\text { S. cerevisiae } \\
\text { C. albicans } \\
\text { C. neoformans }\end{array}$ & {$[194,262-266]$} \\
\hline Fluconazole & $\begin{array}{c}\text { TAC1, MRR1, } \\
\text { CDR1 and CDR2 }\end{array}$ & $\begin{array}{l}\text { Increased copy } \\
\text { number }\end{array}$ & C. albicans & {$[262,266]$} \\
\hline Fluconazole & $\begin{array}{c}\text { AFR1, SEY1 and } \\
\text { GLO3 }\end{array}$ & $\begin{array}{l}\text { Increased copy } \\
\text { number }\end{array}$ & C. neoformans & [263-265] \\
\hline $\begin{array}{l}\text { Fluconazole, } \\
\text { amphotericin B, } \\
\text { caspofungin }\end{array}$ & & $\begin{array}{l}\text { Chr V } \\
\text { monosomy }\end{array}$ & C. albicans & {$[200,267]$} \\
\hline Itraconazole & $p d m A$ & $\begin{array}{l}\text { Increased copy } \\
\text { number }\end{array}$ & $\begin{array}{l}\text { Aspergillus } \\
\text { fumigatus }\end{array}$ & [268] \\
\hline Radicicol & STI1, PDR5 & $\begin{array}{l}\text { Increased copy } \\
\text { number }\end{array}$ & S. cerevisiae & [194] \\
\hline Tunicamycin & $\begin{array}{l}\text { ALG7, PRE7, } \\
\text { YBR085C-A }\end{array}$ & $\begin{array}{l}\text { Increased copy } \\
\text { number }\end{array}$ & S. cerevisiae & [199] \\
\hline $\begin{array}{l}\text { 4-Nitroquinoline-N- } \\
\text { oxide }\end{array}$ & ATR1 & $\begin{array}{l}\text { Increased copy } \\
\text { number }\end{array}$ & S. cerevisiae & [90] \\
\hline $\begin{array}{c}\text { Sterol demethylase } \\
\text { inhibitors }\end{array}$ & Mutated CYP51 & $\begin{array}{l}\text { Increased copy } \\
\text { number }\end{array}$ & $\begin{array}{l}\text { Erysiphe } \\
\text { necator }\end{array}$ & [269] \\
\hline $\begin{array}{l}\text { Hydroxyurea, } \\
\text { caspofungin }\end{array}$ & & Chr II trisomy & C. albicans & [200] \\
\hline $\begin{array}{l}\text { Inflammatory host } \\
\text { response }\end{array}$ & & $\begin{array}{l}\text { Chr V or VI } \\
\text { triplication }\end{array}$ & C. albicans & [270] \\
\hline $\begin{array}{l}\text { Modulation of } \\
\text { pathogenicity }\end{array}$ & $\begin{array}{c}\text { Ave1, } \\
\text { XLOC_009059, } \\
\text { XLOC_008951, } \\
\text { etc. }\end{array}$ & $\begin{array}{l}\text { Translocations } \\
\text { and inversions }\end{array}$ & $\begin{array}{l}\text { Verticillium } \\
\text { dahliae }\end{array}$ & [72] \\
\hline \multicolumn{5}{|l|}{$\begin{array}{c}\text { Industrially } \\
\text { relevant phenotype: }\end{array}$} \\
\hline $\begin{array}{l}\text { Improved growth in } \\
\text { maltose-containing } \\
\text { medium }\end{array}$ & $\begin{array}{l}\text { MAL1, MAL3, } \\
M P H 2, M P H 3, \\
\text { and YPR196W }\end{array}$ & $\begin{array}{l}\text { Increased copy } \\
\text { number }\end{array}$ & S. cerevisiae & {$[86,271]$} \\
\hline $\begin{array}{l}\text { Improved growth in } \\
\text { galactose-containing } \\
\text { medium }\end{array}$ & $\begin{array}{l}\text { GAL7, GAL10, } \\
\text { GAL1 }\end{array}$ & $\begin{array}{l}\text { Increased copy } \\
\text { number }\end{array}$ & S. cerevisiae & [187] \\
\hline $\begin{array}{l}\text { Desirable cell } \\
\text { aggregation }\end{array}$ & $\begin{array}{l}\text { FLO1, Lg-FLO1, } \\
\text { FLO5 and FLO10 }\end{array}$ & $\begin{array}{l}\text { Increased copy } \\
\text { number }\end{array}$ & S. cerevisiae & {$[184,272]$} \\
\hline $\begin{array}{l}\text { Low diacetyl } \\
\text { production }\end{array}$ & $I L V 5$ and $I L V 3$ & $\begin{array}{l}\text { Increased copy } \\
\text { number }\end{array}$ & S. pastorianus & [184] \\
\hline $\begin{array}{l}\text { Improved starch } \\
\text { consumption }\end{array}$ & $\alpha$-amylase gene & $\begin{array}{l}\text { Increased copy } \\
\text { number }\end{array}$ & $\begin{array}{c}\text { Aspergillus } \\
\text { oryzae }\end{array}$ & {$[273,274]$} \\
\hline $\begin{array}{c}\text { Increased ethanol } \\
\text { yield }\end{array}$ & & $\begin{array}{c}\text { Chr XI } \\
\text { duplication }\end{array}$ & S. cerevisiae & [28] \\
\hline $\begin{array}{l}\text { Improved xylose } \\
\text { fermentation in the } \\
\text { presence of ferulic } \\
\text { and p-coumaric } \\
\text { acids }\end{array}$ & & $\begin{array}{l}\text { Chr XIV } \\
\text { duplication }\end{array}$ & S. cerevisiae & [275] \\
\hline
\end{tabular}


Table 1. Cont.

\begin{tabular}{|c|c|c|c|c|}
\hline Phenotype & Gene(s) & Type of SV & Organism & References \\
\hline \multicolumn{5}{|l|}{$\begin{array}{l}\text { Compensation of } \\
\text { mutation: }\end{array}$} \\
\hline Deletion of $M E C 1$ & RNR1 & $\begin{array}{l}\text { Increased copy } \\
\text { number }\end{array}$ & S. cerevisiae & [276] \\
\hline Deficiency of EST2 & $\begin{array}{c}\text { PRP8, UTP9, } \\
\text { KOG1, and SCH9 }\end{array}$ & $\begin{array}{l}\text { Chr VIII } \\
\text { monosomy }\end{array}$ & S. cerevisiae & [202] \\
\hline Deletion of $R N R 1$ & RNR3 & $\begin{array}{l}\text { Increased copy } \\
\text { number }\end{array}$ & S. cerevisiae & [206] \\
\hline Deletion of RPS24A & RPS24B & $\begin{array}{l}\text { Increased copy } \\
\text { number }\end{array}$ & S. cerevisiae & [206] \\
\hline Deletion of $\mathrm{MYO} 2$ & RLM1 & $\begin{array}{l}\text { Increased copy } \\
\text { number }\end{array}$ & S. cerevisiae & [91] \\
\hline Deletion of JEN1 & $A D Y 2$ & $\begin{array}{l}\text { Increased copy } \\
\text { number + SNV }\end{array}$ & S. cerevisiae & {$[277]$} \\
\hline Deletion of $G A L 7$ & GAL80 & $\begin{array}{l}\text { Increased copy } \\
\text { number }\end{array}$ & S. cerevisiae & {$[278]$} \\
\hline Deletion of $R G D 1$ & NPR2 & $\begin{array}{l}\text { Increased copy } \\
\text { number }\end{array}$ & C. albicans & [279] \\
\hline
\end{tabular}

${ }^{1}$ Tetraploid-specific effect.

The recent genome-wide association study performed on 1011 yeast strains identified $22 \mathrm{CNV}$ s that were strongly associated with improved growth under stress conditions such as at high temperature $\left(40^{\circ} \mathrm{C}\right.$, PAU 5 and several genes introgressed from S. paradoxus), elevated concentration of copper sulfate (metallothionein CUP1), sodium chloride $\left(\mathrm{Na}^{+}\right.$efflux ATPase ENA5, component of the mitochondria-ER-cortex-anchor MDM36 and VAR1589 introgressed from $S$. paradoxus), lithium chloride (ENA5 and VAR1589), antifungal drug nystatin treatments (alcohol dehydrogenase $A D H 4$ and hexokinase HXK2), presence of sodium meta-arsenite (subtelomeric region of chromosome XVI containing ARR1, ARR2, and $A R R 3$ genes, known be essential for resistance to arsenic compounds [280] as well as YPR196W, YPR195C, SGE1, AQY1, and HPA2), and on medium with galactose as the carbon source (two genes introgressed from $S$. paradoxus) [148].

Importantly, these associations between specific CNVs and stress tolerance are often confirmed by other studies. The results of the recent third-generation sequencing effort that provided a high-resolution picture of the $S$. cerevisiae and S. paradoxus subtelomeric regions, and CUP1 and $A R R$ clusters in particular, further confirm these associations between the gene copy numbers in these clusters and resistance to high-copper and higharsenic conditions [65]. Similarly, the duplication of CUP1, alongside with increased copy number of CUP2, SCO1, and SCO2, were previously implicated in increased copper tolerance of both environmental $S$. cerevisiae isolates and strains subjected to experimental evolution [250-252]. Another example of CNV-mediated stress adaptation is freeze-thaw tolerance of an environmental isolates of $S$. cerevisiae and Saccharomyces paradoxus, which was associated with CNV involving the $A Q Y 2$ water-transporter gene [182,253]. Increased expression of 17 genes due to duplication of chromosome III (of which HCM1, YCR016W, RRT12, YCR102C, and IMG2 showed the highest contribution) was linked to increased heat tolerance of experimentally evolved S. cerevisiae strains [195]. Large segmental duplications and aneuploidization involving this chromosome were iteratively found in association with improved heat tolerance [254,255].

Extensive genomic and phenomic studies revealed that CNVs also underlie some of the specific characteristics of industrial $S$. cerevisiae strains $[86,87,89]$. The genes most frequently present in variable copy numbers in different strains include those involved in nitrogen and carbon metabolism, ion transport, and flocculation $[86,87,89]$. Interestingly, there seem to be an association between some CNVs and particular environmental niches, indicating the potential adaptive nature of those CNVs [86]. For instance, genes involved in uptake and breakdown of maltose, such as MAL1, MAL3, MPH2, MPH3, and YPR196W, 
are often amplified in beer strains that are adapted to fermenting maltose-containing wort, whereas they are often lost in wine strains that are adapted to grape must, which does not contain maltose $[86,271]$. In addition, CNVs involving the flocculation gene FLO1, Lg-FLO1, FLO5 and FLO10 were implicated in conferring desirable cell aggregation in industrial beer strains $[184,272]$. Low diacetyl production, another industrially relevant characteristic of $S$. pastorianus beer strains, was shown to rely on increased copy number of ILV5 and ILV3 genes, encoding enzymes that catalyze reactions converting diacetyl precursor $\alpha$-acetolactate into $\alpha$-keto-isovalerate, thus reducing the amount of $\alpha$-acetolactate that can be converted into diacetyl via chemical oxidative decarboxylation [184].

In wine $S$. cerevisiae isolates, potentially adaptive $\mathrm{CNV}$ s include loci containing genes encoding various transporters, dehydrogenases and genes involved in the metabolism and efflux of toxic subtances that are sometimes used in winemaking, such as copper and sulfite $[88,281,282]$. Similarly, for S. cerevisiae dairy strains, duplication of the galactose permease GAL2 gene and the introgressed GAL7-GAL10-GAL1 gene cluster allows elevated galactose utilization rate [187]. Another example of domestication-driven phenotype boosted by gene duplication is the copy number amplification of $\alpha$-amylase gene in filamentous fungus Aspergillus oryzae used for metabolizing starch found in rice kernels $[273,274]$.

SV events leading to increased copy numbers of certain genetic loci were shown to be involved in increasing drug resistance of various fungi. The recurrent theme is that increasing the dosage of the drug targets or of genes that help to clear the drugs, convey resistance. For instance, resistance towards the widely used antifungal drug fluconazole in a broad range of yeasts, ranging from S. cerevisiae laboratory strains and clinical isolates to pathogenic Candida albicans and Cryptococcus neoformans strains, is acquired via gain of extra copies of ERG11, encoding the lanosterol 14-alpha-demethylase enzyme in the ergosterol pathway that is targeted by this drug [194,262-266]. In addition, duplication of TAC1, MRR1, CDR1 and CDR2 in C. albicans and AFR1, SEY1 and GLO3 in C. neoformans were also reported to be involved in conveying resistance to fluconazole [262-266]. Resistance to another antifungal drug, itraconazole, in the human pathogen Aspergillus fumigatus is conferred by the extra copies of cytochrome P-450-depdendent C-14 lanosterol $\alpha$-demethylase $p d m A$ [268]. Increased copy number of the mutated allele of CYP51 gene is associated with the increased resistance towards sterol demethylase inhibitor fungicides in grape powdery mildew pathogen Erysiphe necator [269]. Similarly, in S. cerevisiae, chromosome XV aneuploidy-mediated increase in gene dosages of Hsp90 cochaperone STI1 and multidrug transporter PDR5 drives the resistance to Hsp90 inhibitor radicicol [194], while resistance to the endoplasmic stress inducer tunicamycin can be achieved by duplication of several genes located on chromosome II, including UDP-N-acetylglucosamine-1-P transferase $A L G 7$, a subunit of the 20S proteasome PRE7, and YBR085C-A [199]. Finally, resistance to the tumorigenic compound 4-nitroquinoline-N-oxide is conferred by an extra copy of the multidrug efflux pump ATR1 [90].

The effects of some deleterious mutations can also be suppressed by $\mathrm{CNV}$ events. In S. cerevisiae, for example, the deletion of the essential genome integrity checkpoint gene $M E C 1$ is rescued via duplication of large subunit of ribonucleotide-diphosphate reductase RNR1 [276]. Similarly, in diploids, telomerase insufficiency triggered by growth at elevated temperatures and associated with the deficiency of telomerase catalytic subunit Est2 [202] is suppressed by chromosome VIII monosomy, resulting in the reduction in the copy numbers of PRP8, UTP9, KOG1, and SCH9 genes that are connected to ribosome production [203]. The slow growth phenotype resulting from the deletion of RNR1 and $R P S 24 A$ can be rescued by increased gene dosage of the paralogues of the deleted genes (RNR3 and RPS24B, respectively) [206]. Deletion of the type II myosin heavy chain gene MYO2 involved in cytokinesis is suppressed by the duplication of transcription factor RLM1 implicated in cell wall remodeling and MAP kinase kinase MKK2 regulated by the indicated transcription factor [91]. The laboratory evolution of S. cerevisiae strain bearing the deletion of the only documented lactate transporter JEN1 for restoration of lactate transport resulted in duplication of the ADY2 monocarboxylate-transporter gene and was 
accompanied by point mutations of the duplicated allele, increasing its lactate transporter efficiency [277]. In a S. cerevisiae model of galactosemia, a $\Delta$ gal7 strain characterized by the buildup of galactitol and D-galactose-1P, an extra copy of the transcriptional repressor of multiple genes in the galactose utilization pathway GAL80 was shown to mediate the galactose tolerance [278]. In C. albicans, the fluconazole resistance lost after deletion of RHOGTPase activator gene $R G D 1$ was restored via duplication of a putative urea transporter NPR2 [279].

There are also many instances when the aneuploidies were shown to be associated with the beneficial phenotypes, but in these instances, pinpointing the loci that drive the adaptation is often difficult. In S. cerevisiae, chromosome III polysomy was identified in the highest ethanol-tolerant natural and fermentative strains [256]. Duplication of the same chromosome as well as chromosome XII was observed in ethanol-tolerant variants resulting from a directed evolution study where populations were grown in the presence of high ethanol concentrations [93]. Duplication of chromosome XI is associated with increased ethanol yield [28]. Presence of an extra copy of chromosome XIV was linked to improved xylose fermentation in the presence of ferulic and p-coumaric acids [275]. Acquisition of an additional copy of chromosome XIII improved growth of tetraploid S. cerevisiae strains in a poor carbon-source medium raffinose [64]. Interestingly, the effect seemed exclusive to tetraploids and was not observed in diploids.

Akin to CNV events, aneuploidies can also affect the pathogenicity of yeasts. In $S$. cerevisiae clinical isolates, aneuploidies have been linked to increased host survival [185]. During experimental oropharyngeal infection in mice, C. albicans strains bearing triplication of chromosomes V or VI were able to achieve the same oral fungal burden as the diploid progenitor strain while eliciting a significantly lower inflammatory host response and causing significantly less weight loss of the infected animals (commensal-like phenotype) [270]. The loss of chromosome $\mathrm{V}$ increased tolerance to antifungals with different mechanisms of action (fluconazole, andamphotericin B, and caspofungin) [200,267], as well as conveyed the ability to utilize $L$-sorbose as a carbon source due to upregulation of sorbose SOU1 [249]. Finally, chromosome II trisomy was shown to increase $C$. albicans tolerance to hydroxyurea or caspofungin [200].

Interestingly, there are also examples of adaptation mediated by SV events that do not involve gene duplication. For example, inversion of the DAL2 gene encoding allantoicase in S. cerevisiae results in decreased expression of this gene and reduced yeast fitness during nitrogen starvation. This SV event also changed the expression of the neighboring genes DAL1 and DAL4 [283]. Among wine yeasts, adaptive reciprocal translocations between chromosomes VIII and XVI (VIII-t-XVI) and between chromosomes XV and XVI (XV-t-XVI) are widespread $[29,257-260]$. Both translocations result in shortened lag phase in a medium containing sulfite, a commonly used additive that prevents wines from oxidation. The effect of these translocations was traced down to the increased expression of plasma membrane sulfite pump SSU1 due to a promoter switch mediated by the microhomology between the promoters SSU1 and ECM34 (in case of VIII-t-XVI) and SSU1 and ADH1 (in case of XV-t-XVI) $[29,258,260]$. Intriguingly, engineering of the translocations present in Saccharomyces mikatae isolated from nutritionally poor habitats into $S$. cerevisiae allowed the resulting strains to outcompete the parent strain under different physiological conditions, especially under glucose limitation $[239,284]$. Moreover, an inversion in chromosome XVI mediated by a microhomology between the SSU1 and GCR1 regulatory regions was also shown to increases SSU1 expression and thus sulfite resistance [261].

Another (quite striking) example of the adaptation associated with balanced SV events (translocations and, to a lesser extent, inversions) is the modulation of the aggressiveness towards host of the fungal plant pathogen Verticillium dahliae [72]. By combining short-read and mate-pair sequencing with optical mapping, De Jonge and coauthors discovered that the genomes of the highly and mildly virulent strains of $V$. dahliae were $99.98 \%$ identical in all genomic regions that could be aligned differ by 11 intra- and 17 interchromosomal 
rearrangements [72]. These SV events shaped the lineage-specific segments that contain the genes associated with pathogenicity (Ave1, XLOC_009059, XLOC_008951 and others) [72].

Finally, with the ever-increasing molecular toolbox, it has recently become possible to induce SV at an unprecedented scale and thus investigate the phenotypic outcomes of such induced SV events. One of the most striking demonstrations of the adaptive power of SV has come from the ongoing Sc2.0 project where a large team of researchers is assembling a synthetic $S$. cerevisiae genome interspersed with recombination sites that can be triggered to induce SV. Such "reshuffling" of chromosomes (synthetic chromosome rearrangement and modification by loxP-mediated evolution-SCRaMbLE [285]) resulted in multiple SV events per strain and lead to large phenotypic diversity in a wide range of growth conditions allowing identification of strains adapted to high alkali conditions [286], caffeine [287], heat [287,288], ethanol [288], or acetic acid [288]. Additionally, SCRaMbLE has been used to boost the effectiveness of yeast in production of various heterologous metabolites including violacein, carotene, lycopene, and betulinic acid [287,289-293].

\section{Conclusions}

A growing body of evidence reveals the important role of SV in fungal evolution and adaptation. Whereas the majority of examples of adaptive structural variation correspond to CNVs, others can be attributed to transcriptional changes of the genes located within or near the SV event. Aneuploidies as well as other unbalanced SV events resulting in net gain of the genetic material, especially ones affecting the subtelomeric regions characterized by the rampant reshuffling of the genes, seem to serve as an evolutionary "quick fix" solution, allowing yeast populations to rapidly adapt to acute stress, after which further SVs and other mutations gradually compensate the potential detrimental side effects of the original SV event. However, while the appreciation for the adaptive role of SV is rising, many SV events are currently still overlooked due to technical challenges in their detection. The emergence of the third-generation long-read sequencing technologies [294] and next-generation mapping technologies, such as optical mapping, 10x Genomics linked reads and chromosome conformation capture techniques such as Hi-C, will likely uncover many more SV events and put SV even more centerstage in molecular evolution, where it may finally claim its spot next to the more established role of SNPs and smaller InDels.

Author Contributions: Conceptualization, K.J.V. and A.G.; writing and editing, A.G. and K.J.V.; figure and table preparation, A.G.; supervision and funding acquisition, K.J.V. All authors have read and agreed to the published version of the manuscript.

Funding: This research was funded by KU Leuven, European Research Council (ERC) Consolidator Grant CoG682009, Vlaams Instituut voor Biotechnologie (VIB), Fonds voor Wetenschappelijk Onderzoek-Vlaanderen (FWO) and Vlaanderen Agentschap Innoveren \& Ondernemen (VLAIO).

Institutional Review Board Statement: Not applicable.

Informed Consent Statement: Not applicable.

Data Availability Statement: Not applicable.

Acknowledgments: The authors thank Brigida Gallone and Jens Frickel for their helpful discussions and proof-reading of the manuscript.

Conflicts of Interest: The authors declare no conflict of interest.

\section{References}

1. Stewart, N.B.; Rogers, R.L. Chromosomal rearrangements as a source of new gene formation in Drosophila yakuba. PLoS Genet. 2019, 15, e1008314. [CrossRef]

2. Huang, Y.C.; Dang, V.D.; Chang, N.C.; Wang, J. Multiple large inversions and breakpoint rewiring of gene expression in the evolution of the fire ant social supergene. Proc. Biol. Sci. 2018, 285. [CrossRef]

3. Lavington, E.; Kern, A.D. The Effect of Common Inversion Polymorphisms on Patterns of Transcriptional Variation in Drosophila melanogaster. G3 Genes Genomes Genet. 2017, 7, 3659. [CrossRef] 
4. Gamazon, E.R.; Stranger, B.E. The impact of human copy number variation on gene expression. Brief. Funct. Genom. 2015, 14, 352-357. [CrossRef]

5. Radke, D.W.; Lee, C. Adaptive potential of genomic structural variation in human and mammalian evolution. Brief. Funct. Genom. 2015, 14, 358-368. [CrossRef] [PubMed]

6. Thompson, M.J.; Jiggins, C.D. Supergenes and their role in evolution. Heredity 2014, 113, 1-8. [CrossRef] [PubMed]

7. Avril, A.; Purcell, J.; Brelsford, A.; Chapuisat, M. Asymmetric assortative mating and queen polyandry are linked to a supergene controlling ant social organization. Mol. Ecol. 2019, 28, 1428-1438. [CrossRef] [PubMed]

8. Coughlan, J.M.; Willis, J.H. Dissecting the role of a large chromosomal inversion in life history divergence throughout the Mimulus guttatus species complex. Mol. Ecol. 2019, 28, 1343-1357. [CrossRef] [PubMed]

9. Faria, R.; Chaube, P.; Morales, H.E.; Larsson, T.; Lemmon, A.R.; Lemmon, E.M.; Rafajlović, M.; Panova, M.; Ravinet, M.; Johannesson, K.; et al. Multiple chromosomal rearrangements in a hybrid zone between Littorina saxatilis ecotypes. Mol. Ecol. 2019, 28, 1375-1393. [CrossRef]

10. Wellband, K.; Mérot, C.; Linnansaari, T.; Elliott, J.A.K.; Curry, R.A.; Bernatchez, L. Chromosomal fusion and life history-associated genomic variation contribute to within-river local adaptation of Atlantic salmon. Mol. Ecol. 2019, 28, 1439-1459. [CrossRef]

11. Wellenreuther, M.; Mérot, C.; Berdan, E.; Bernatchez, L. Going beyond SNPs: The role of structural genomic variants in adaptive evolution and species diversification. Mol. Ecol. 2019, 28, 1203-1209. [CrossRef] [PubMed]

12. Conrad, D.F.; Pinto, D.; Redon, R.; Feuk, L.; Gokcumen, O.; Zhang, Y.; Aerts, J.; Andrews, T.D.; Barnes, C.; Campbell, P.; et al. Origins and functional impact of copy number variation in the human genome. Nature 2010, 464, 704-712. [CrossRef] [PubMed]

13. Sudmant, P.H.; Rausch, T.; Gardner, E.J.; Handsaker, R.E.; Abyzov, A.; Huddleston, J.; Zhang, Y.; Ye, K.; Jun, G.; Fritz, M.H.; et al. An integrated map of structural variation in 2504 human genomes. Nature 2015, 526, 75-81. [CrossRef] [PubMed]

14. Jeffares, D.C.; Jolly, C.; Hoti, M.; Speed, D.; Shaw, L.; Rallis, C.; Balloux, F.; Dessimoz, C.; Bähler, J.; Sedlazeck, F.J. Transient structural variations have strong effects on quantitative traits and reproductive isolation in fission yeast. Nat. Commun. 2017, 8, 14061. [CrossRef] [PubMed]

15. Audano, P.A.; Sulovari, A.; Graves-Lindsay, T.A.; Cantsilieris, S.; Sorensen, M.; Welch, A.E.; Dougherty, M.L.; Nelson, B.J.; Shah, A.; Dutcher, S.K.; et al. Characterizing the Major Structural Variant Alleles of the Human Genome. Cell 2019, 176, 663-675.e619. [CrossRef] [PubMed]

16. Weischenfeldt, J.; Symmons, O.; Spitz, F.; Korbel, J.O. Phenotypic impact of genomic structural variation: Insights from and for human disease. Nat. Rev. Genet. 2013, 14, 125-138. [CrossRef]

17. Hollox, E.J.; Huffmeier, U.; Zeeuwen, P.L.J.M.; Palla, R.; Lascorz, J.; Rodijk-Olthuis, D.; van de Kerkhof, P.C.M.; Traupe, H.; de Jongh, G.; Heijer, M.D.; et al. Psoriasis is associated with increased $\beta$-defensin genomic copy number. Nat. Genet. 2008, 40, 23-25. [CrossRef]

18. Stefansson, H.; Rujescu, D.; Cichon, S.; Pietilainen, O.P.; Ingason, A.; Steinberg, S.; Fossdal, R.; Sigurdsson, E.; Sigmundsson, T.; Buizer-Voskamp, J.E.; et al. Large recurrent microdeletions associated with schizophrenia. Nature 2008, 455, 232-236. [CrossRef]

19. Traherne, J.A.; Martin, M.; Ward, R.; Ohashi, M.; Pellett, F.; Gladman, D.; Middleton, D.; Carrington, M.; Trowsdale, J. Mechanisms of copy number variation and hybrid gene formation in the KIR immune gene complex. Hum. Mol. Genet. 2010, 19, 737-751. [CrossRef] [PubMed]

20. Polley, S.; Louzada, S.; Forni, D.; Sironi, M.; Balaskas, T.; Hains, D.S.; Yang, F.; Hollox, E.J. Evolution of the rapidly mutating human salivary agglutinin gene (DMBT1) and population subsistence strategy. Proc. Natl. Acad. Sci. USA 2015, 112, 5105-5110. [CrossRef] [PubMed]

21. Durbin, R.M.; Altshuler, D.; Durbin, R.M.; Abecasis, G.R.; Bentley, D.R.; Chakravarti, A.; Clark, A.G.; Collins, F.S.; De La Vega, F.M.; Donnelly, P.; et al. A map of human genome variation from population-scale sequencing. Nature 2010, 467, 1061-1073. [CrossRef]

22. Weissensteiner, M.H.; Bunikis, I.; Catalan, A.; Francoijs, K.J.; Knief, U.; Heim, W.; Peona, V.; Pophaly, S.D.; Sedlazeck, F.J.; Suh, A.; et al. Discovery and population genomics of structural variation in a songbird genus. Nat. Commun. 2020, 11, 3403. [CrossRef]

23. Catanach, A.; Crowhurst, R.; Deng, C.; David, C.; Bernatchez, L.; Wellenreuther, M. The genomic pool of standing structural variation outnumbers single nucleotide polymorphism by threefold in the marine teleost Chrysophrys auratus. Mol. Ecol. 2019, 28, 1210-1223. [CrossRef] [PubMed]

24. Lucek, K.; Gompert, Z.; Nosil, P. The role of structural genomic variants in population differentiation and ecotype formation in Timema cristinae walking sticks. Mol. Ecol. 2019, 28, 1224-1237. [CrossRef] [PubMed]

25. Chakraborty, M.; Emerson, J.J.; Macdonald, S.J.; Long, A.D. Structural variants exhibit widespread allelic heterogeneity and shape variation in complex traits. Nat. Commun. 2019, 10, 4872. [CrossRef]

26. Fisher, K.J.; Buskirk, S.W.; Vignogna, R.C.; Marad, D.A.; Lang, G.I. Adaptive genome duplication affects patterns of molecular evolution in Saccharomyces cerevisiae. PLoS Genet. 2018, 14, e1007396. [CrossRef] [PubMed]

27. Steenwyk, J.; Rokas, A. Extensive Copy Number Variation in Fermentation-Related Genes among Saccharomyces cerevisiae Wine Strains. G3 Genes Genomes Genet. 2017, 7, 1475. [CrossRef]

28. Zhang, K.; Zhang, L.J.; Fang, Y.H.; Jin, X.N.; Qi, L.; Wu, X.C.; Zheng, D.Q. Genomic structural variation contributes to phenotypic change of industrial bioethanol yeast Saccharomyces cerevisiae. FEMS Yeast Res. 2016, 16, 118. [CrossRef] [PubMed]

29. Treu, L.; Toniolo, C.; Nadai, C.; Sardu, A.; Giacomini, A.; Corich, V.; Campanaro, S. The impact of genomic variability on gene expression in environmental Saccharomyces cerevisiae strains. Environ. Microbiol. 2014, 16, 1378-1397. [CrossRef] 
30. Gresham, D.; Desai, M.M.; Tucker, C.M.; Jenq, H.T.; Pai, D.A.; Ward, A.; DeSevo, C.G.; Botstein, D.; Dunham, M.J. The Repertoire and Dynamics of Evolutionary Adaptations to Controlled Nutrient-Limited Environments in Yeast. PLoS Genet. 2008, 4, e1000303. [CrossRef]

31. Dunham, M.J.; Badrane, H.; Ferea, T.; Adams, J.; Brown, P.O.; Rosenzweig, F.; Botstein, D. Characteristic genome rearrangements in experimental evolution of Saccharomyces cerevisiae. Proc. Natl. Acad. Sci. USA 2002, 99, 16144. [CrossRef]

32. Thompson, S.L.; Bakhoum, S.F.; Compton, D.A. Mechanisms of chromosomal instability. Curr. Biol. 2010, 20, R285-R295. [CrossRef]

33. Myung, K.; Datta, A.; Kolodner, R.D. Suppression of spontaneous chromosomal rearrangements by S phase checkpoint functions in Saccharomyces cerevisiae. Cell 2001, 104, 397-408. [CrossRef]

34. Labib, K.; Hodgson, B. Replication fork barriers: Pausing for a break or stalling for time? EMBO Rep. 2007, 8, 346-353. [CrossRef]

35. Admire, A.; Shanks, L.; Danzl, N.; Wang, M.; Weier, U.; Stevens, W.; Hunt, E.; Weinert, T. Cycles of chromosome instability are associated with a fragile site and are increased by defects in DNA replication and checkpoint controls in yeast. Genes Dev. 2006, 20, 159-173. [CrossRef]

36. Brewer, B.J.; Lockshon, D.; Fangman, W.L. The arrest of replication forks in the rDNA of yeast occurs independently of transcription. Cell 1992, 71, 267-276. [CrossRef]

37. Paeschke, K.; Bochman, M.L.; Garcia, P.D.; Cejka, P.; Friedman, K.L.; Kowalczykowski, S.C.; Zakian, V.A. Pif1 family helicases suppress genome instability at G-quadruplex motifs. Nature 2013, 497, 458-462. [CrossRef] [PubMed]

38. Wallgren, M.; Mohammad, J.B.; Yan, K.-P.; Pourbozorgi-Langroudi, P.; Ebrahimi, M.; Sabouri, N. G-rich telomeric and ribosomal DNA sequences from the fission yeast genome form stable G-quadruplex DNA structures in vitro and are unwound by the Pfh1 DNA helicase. Nucleic Acids Res. 2016, 44, 6213-6231. [CrossRef]

39. Capra, J.A.; Paeschke, K.; Singh, M.; Zakian, V.A. G-quadruplex DNA sequences are evolutionarily conserved and associated with distinct genomic features in Saccharomyces cerevisiae. PLoS Comput. Biol. 2010, 6, e1000861. [CrossRef] [PubMed]

40. Hershman, S.G.; Chen, Q.; Lee, J.Y.; Kozak, M.L.; Yue, P.; Wang, L.S.; Johnson, F.B. Genomic distribution and functional analyses of potential G-quadruplex-forming sequences in Saccharomyces cerevisiae. Nucleic Acids Res. 2008, 36, 144-156. [CrossRef] [PubMed]

41. Huppert, J.L.; Balasubramanian, S. Prevalence of quadruplexes in the human genome. Nucleic Acids Res. 2005, 33, 2908-2916. [CrossRef] [PubMed]

42. Sabouri, N.; Capra, J.A.; Zakian, V.A. The essential Schizosaccharomyces pombe Pfh1 DNA helicase promotes fork movement past G-quadruplex motifs to prevent DNA damage. BMC Biol. 2014, 12, 1-14. [CrossRef]

43. Huppert, J.L.; Balasubramanian, S. G-quadruplexes in promoters throughout the human genome. Nucleic Acids Res. 2007, 35, 406-413. [CrossRef]

44. Drygin, D.; Siddiqui-Jain, A.; O’Brien, S.; Schwaebe, M.; Lin, A.; Bliesath, J.; Ho, C.B.; Proffitt, C.; Trent, K.; Whitten, J.P. Anticancer activity of CX-3543: A direct inhibitor of rRNA biogenesis. Cancer Res. 2009, 69, 7653-7661. [CrossRef]

45. Ivessa, A.S.; Lenzmeier, B.A.; Bessler, J.B.; Goudsouzian, L.K.; Schnakenberg, S.L.; Zakian, V.A. The Saccharomyces cerevisiae helicase Rrm3p facilitates replication past nonhistone protein-DNA complexes. Mol. Cell 2003, 12, 1525-1536. [CrossRef]

46. Lin, Y.-L.; Pasero, P. Interference between DNA replication and transcription as a cause of genomic instability. Curr. Genom. 2012, 13, 65-73. [CrossRef] [PubMed]

47. Gaillard, H.; Aguilera, A. Transcription as a threat to genome integrity. Annu. Rev. Biochem. 2016, 85, 291-317. [CrossRef]

48. Cabral, M.; Cheng, X.; Singh, S.; Ivessa, A.S. Absence of Non-histone Protein Complexes at Natural Chromosomal Pause Sites Results in Reduced Replication Pausing in Aging Yeast Cells. Cell Rep. 2016, 17, 1747-1754. [CrossRef] [PubMed]

49. Lambert, S.; Watson, A.; Sheedy, D.M.; Martin, B.; Carr, A.M. Gross chromosomal rearrangements and elevated recombination at an inducible site-specific replication fork barrier. Cell 2005, 121, 689-702. [CrossRef] [PubMed]

50. Bester, A.C.; Roniger, M.; Oren, Y.S.; Im, M.M.; Sarni, D.; Chaoat, M.; Bensimon, A.; Zamir, G.; Shewach, D.S.; Kerem, B. Nucleotide deficiency promotes genomic instability in early stages of cancer development. Cell 2011, 145, 435-446. [CrossRef] [PubMed]

51. Saldivar, J.C.; Miuma, S.; Bene, J.; Hosseini, S.A.; Shibata, H.; Sun, J.; Wheeler, L.J.; Mathews, C.K.; Huebner, K. Initiation of genome instability and preneoplastic processes through loss of Fhit expression. PLoS Genet. 2012, 8, e1003077. [CrossRef] [PubMed]

52. Lambert, S.; Mizuno, K.I.; Blaisonneau, J.; Martineau, S.; Chanet, R.; Fréon, K.; Murray, J.M.; Carr, A.M.; Baldacci, G. Homologous recombination restarts blocked replication forks at the expense of genome rearrangements by template exchange. Mol. Cell 2010, 39, 346-359. [CrossRef]

53. Mizuno, K.I.; Lambert, S.; Baldacci, G.; Murray, J.M.; Carr, A.M. Nearby inverted repeats fuse to generate acentric and dicentric palindromic chromosomes by a replication template exchange mechanism. Genes Dev. 2009, 23, 2876-2886. [CrossRef]

54. Payen, C.; Koszul, R.; Dujon, B.; Fischer, G. Segmental duplications arise from Pol32-dependent repair of broken forks through two alternative replication-based mechanisms. PLoS Genet. 2008, 4, e1000175. [CrossRef] [PubMed]

55. Petes, T.D. Unequal meiotic recombination within tandem arrays of yeast ribosomal DNA genes. Cell 1980, 19, 765-774. [CrossRef]

56. Szostak, J.W.; Wu, R. Unequal crossing over in the ribosomal DNA of Saccharomyces cerevisiae. Nature 1980, 284, 426-430. [CrossRef]

57. Welch, J.W.; Maloney, D.H.; Fogel, S. Unequal crossing-over and gene conversion at the amplified CUP1 locus of yeast. Mol. Gen. Genet. MGG 1990, 222, 304-310. [CrossRef] [PubMed] 
58. Gangloff, S.; Zou, H.; Rothstein, R. Gene conversion plays the major role in controlling the stability of large tandem repeats in yeast. EMBO J. 1996, 15, 1715-1725. [CrossRef] [PubMed]

59. Ozenberger, B.A.; Roeder, G.S. A unique pathway of double-strand break repair operates in tandemly repeated genes. Mol. Cell. Biol. 1991, 11, 1222-1231. [CrossRef]

60. Fischer, G.; James, S.; Roberts, I.; Oliver, S.; Louis, E. Chromosomal evolution in Saccharomyces. Nature 2000, 405, 451-454. [CrossRef]

61. Stankiewicz, P.; Lupski, J.R. Genome architecture, rearrangements and genomic disorders. Trends Genet. 2002, 18, 74-82. [CrossRef]

62. Kellis, M.; Patterson, N.; Endrizzi, M.; Birren, B.; Lander, E.S. Sequencing and comparison of yeast species to identify genes and regulatory elements. Nature 2003, 423, 241-254. [CrossRef] [PubMed]

63. Gordon, J.L.; Byrne, K.P.; Wolfe, K.H. Additions, losses, and rearrangements on the evolutionary route from a reconstructed ancestor to the modern Saccharomyces cerevisiae genome. PLoS Genet. 2009, 5, e1000485. [CrossRef] [PubMed]

64. Selmecki, A.M.; Maruvka, Y.E.; Richmond, P.A.; Guillet, M.; Shoresh, N.; Sorenson, A.L.; De, S.; Kishony, R.; Michor, F.; Dowell, R. Polyploidy can drive rapid adaptation in yeast. Nature 2015, 519, 349-352. [CrossRef] [PubMed]

65. Yue, J.-X.; Li, J.; Aigrain, L.; Hallin, J.; Persson, K.; Oliver, K.; Bergström, A.; Coupland, P.; Warringer, J.; Lagomarsino, M.C.; et al. Contrasting evolutionary genome dynamics between domesticated and wild yeasts. Nat. Genet. 2017, 49, 913-924. [CrossRef] [PubMed]

66. Sui, Y.; Qi, L.; Wu, J.-K.; Wen, X.-P.; Tang, X.-X.; Ma, Z.-J.; Wu, X.-C.; Zhang, K.; Kokoska, R.J.; Zheng, D.-Q.; et al. Genome-wide mapping of spontaneous genetic alterations in diploid yeast cells. Proc. Natl. Acad. Sci. USA 2020, 117, 28191. [CrossRef] [PubMed]

67. Kaya, A.; Mariotti, M.; Tyshkovskiy, A.; Zhou, X.; Hulke, M.L.; Ma, S.; Gerashchenko, M.V.; Koren, A.; Gladyshev, V.N. Molecular signatures of aneuploidy-driven adaptive evolution. Nat. Commun. 2020, 11, 588. [CrossRef]

68. Raffaele, S.; Farrer, R.A.; Cano, L.M.; Studholme, D.J.; MacLean, D.; Thines, M.; Jiang, R.H.Y.; Zody, M.C.; Kunjeti, S.G.; Donofrio, N.M.; et al. Genome Evolution Following Host Jumps in the Irish Potato Famine Pathogen Lineage. Science 2010, $330,1540$. [CrossRef]

69. Ma, L.-J.; van der Does, H.C.; Borkovich, K.A.; Coleman, J.J.; Daboussi, M.-J.; Di Pietro, A.; Dufresne, M.; Freitag, M.; Grabherr, M.; Henrissat, B. Comparative genomics reveals mobile pathogenicity chromosomes in Fusarium. Nature 2010, 464, 367-373. [CrossRef]

70. Klosterman, S.J.; Subbarao, K.V.; Kang, S.; Veronese, P.; Gold, S.E.; Thomma, B.P.; Chen, Z.; Henrissat, B.; Lee, Y.-H.; Park, J. Comparative genomics yields insights into niche adaptation of plant vascular wilt pathogens. PLoS Pathog. 2011, 7, e1002137. [CrossRef]

71. Chuma, I.; Isobe, C.; Hotta, Y.; Ibaragi, K.; Futamata, N.; Kusaba, M.; Yoshida, K.; Terauchi, R.; Fujita, Y.; Nakayashiki, H. Multiple translocation of the AVR-Pita effector gene among chromosomes of the rice blast fungus Magnaporthe oryzae and related species. PLoS Pathog. 2011, 7, e1002147. [CrossRef] [PubMed]

72. De Jonge, R.; Bolton, M.D.; Kombrink, A.; van den Berg, G.C.M.; Yadeta, K.A.; Thomma, B.P.H.J. Extensive chromosomal reshuffling drives evolution of virulence in an asexual pathogen. Genome Res. 2013, 23, 1271-1282. [CrossRef] [PubMed]

73. Faino, L.; Seidl, M.F.; Shi-Kunne, X.; Pauper, M.; van den Berg, G.C.; Wittenberg, A.H.; Thomma, B.P. Transposons passively and actively contribute to evolution of the two-speed genome of a fungal pathogen. Genome Res. 2016, 26, 1091-1100. [CrossRef]

74. Plissonneau, C.; Stürchler, A.; Croll, D. The Evolution of Orphan Regions in Genomes of a Fungal Pathogen of Wheat. $m$ Bio 2016, 7, e01231-16. [CrossRef]

75. Hastings, P.J.; Lupski, J.R.; Rosenberg, S.M.; Ira, G. Mechanisms of change in gene copy number. Nat. Rev. Genet. 2009, 10, 551-564. [CrossRef]

76. Carvalho, C.M.; Lupski, J.R. Mechanisms underlying structural variant formation in genomic disorders. Nat. Rev. Genet. 2016, 17, 224-238. [CrossRef] [PubMed]

77. Brewer, B.J.; Payen, C.; Raghuraman, M.K.; Dunham, M.J. Origin-dependent inverted-repeat amplification: A replication-based model for generating palindromic amplicons. PLoS Genet. 2011, 7, e1002016. [CrossRef] [PubMed]

78. Brewer, B.J.; Payen, C.; Di Rienzi, S.C.; Higgins, M.M.; Ong, G.; Dunham, M.J.; Raghuraman, M.K. Origin-Dependent InvertedRepeat Amplification: Tests of a Model for Inverted DNA Amplification. PLoS Genet. 2015, 11, e1005699. [CrossRef] [PubMed]

79. Gresham, D.; Usaite, R.; Germann, S.M.; Lisby, M.; Botstein, D.; Regenberg, B. Adaptation to diverse nitrogen-limited environments by deletion or extrachromosomal element formation of the GAP1 locus. Proc. Natl. Acad. Sci. USA 2010, 107, 18551-18556. [CrossRef]

80. Møller, H.D.; Andersen, K.S.; Regenberg, B. A model for generating several adaptive phenotypes from a single genetic event: Saccharomyces cerevisiae GAP1 as a potential bet-hedging switch. Commun. Integr. Biol. 2013, 6, e23933. [CrossRef]

81. Cohen, S.; Segal, D. Extrachromosomal circular DNA in eukaryotes: Possible involvement in the plasticity of tandem repeats. Cytogenet. Genome Res. 2009, 124, 327-338. [CrossRef]

82. Pontes, O.; Neves, N.; Silva, M.; Lewis, M.S.; Madlung, A.; Comai, L.; Viegas, W.; Pikaard, C.S. Chromosomal locus rearrangements are a rapid response to formation of the allotetraploid Arabidopsis suecica genome. Proc. Natl. Acad. Sci. USA 2004, 101, 18240-18245. [CrossRef]

83. Madlung, A.; Tyagi, A.P.; Watson, B.; Jiang, H.; Kagochi, T.; Doerge, R.W.; Martienssen, R.; Comai, L. Genomic changes in synthetic Arabidopsis polyploids. Plant J. 2005, 41, 221-230. [CrossRef] 
84. Ohno, S.; Wolf, U.; Atkin, N.B. Evolution from fish to mammals by gene duplication. Hereditas 1968, 59, 169-187. [CrossRef]

85. Ohno, S. Evolution by Gene Duplication; Springer Science \& Business Media: Berlin, Germany, 2013.

86. Gallone, B.; Steensels, J.; Prahl, T.; Soriaga, L.; Saels, V.; Herrera-Malaver, B.; Merlevede, A.; Roncoroni, M.; Voordeckers, K.; Miraglia, L.; et al. Domestication and Divergence of Saccharomyces cerevisiae Beer Yeasts. Cell 2016, 166, 1397-1410.e1316. [CrossRef] [PubMed]

87. Bergström, A.; Simpson, J.T.; Salinas, F.; Barré, B.; Parts, L.; Zia, A.; Nguyen Ba, A.N.; Moses, A.M.; Louis, E.J.; Mustonen, V.; et al. A High-Definition View of Functional Genetic Variation from Natural Yeast Genomes. Mol. Biol. Evol. 2014, 31, 872-888. [CrossRef] [PubMed]

88. Borneman, A.R.; Desany, B.A.; Riches, D.; Affourtit, J.P.; Forgan, A.H.; Pretorius, I.S.; Egholm, M.; Chambers, P.J. Whole-Genome Comparison Reveals Novel Genetic Elements That Characterize the Genome of Industrial Strains of Saccharomyces cerevisiae. PLoS Genet. 2011, 7, e1001287. [CrossRef]

89. Dunn, B.; Richter, C.; Kvitek, D.J.; Pugh, T.; Sherlock, G. Analysis of the Saccharomyces cerevisiae pan-genome reveals a pool of copy number variants distributed in diverse yeast strains from differing industrial environments. Genome Res. 2012, 22, 908-924. [CrossRef] [PubMed]

90. Pavelka, N.; Rancati, G.; Zhu, J.; Bradford, W.D.; Saraf, A.; Florens, L.; Sanderson, B.W.; Hattem, G.L.; Li, R. Aneuploidy confers quantitative proteome changes and phenotypic variation in budding yeast. Nature 2010, 468, 321-325. [CrossRef]

91. Rancati, G.; Pavelka, N.; Fleharty, B.; Noll, A.; Trimble, R.; Walton, K.; Perera, A.; Staehling-Hampton, K.; Seidel, C.W.; Li, R. Aneuploidy Underlies Rapid Adaptive Evolution of Yeast Cells Deprived of a Conserved Cytokinesis Motor. Cell 2008, 135, 879-893. [CrossRef] [PubMed]

92. Selmecki, A.M.; Dulmage, K.; Cowen, L.E.; Anderson, J.B.; Berman, J. Acquisition of aneuploidy provides increased fitness during the evolution of antifungal drug resistance. PLoS Genet. 2009, 5, e1000705. [CrossRef]

93. Voordeckers, K.; Kominek, J.; Das, A.; Espinosa-Cantú, A.; de Maeyer, D.; Arslan, A.; van Pee, M.; van der Zande, E.; Meert, W.; Yang, Y.; et al. Adaptation to High Ethanol Reveals Complex Evolutionary Pathways. PLoS Genet. 2015, 11, e1005635. [CrossRef]

94. Purugganan, M.D.; Fuller, D.Q. The nature of selection during plant domestication. Nature 2009, 457, 843-848. [CrossRef]

95. Low, W.Y.; Tearle, R.; Liu, R.; Koren, S.; Rhie, A.; Bickhart, D.M.; Rosen, B.D.; Kronenberg, Z.N.; Kingan, S.B.; Tseng, E.; et al. Haplotype-resolved genomes provide insights into structural variation and gene content in Angus and Brahman cattle. Nat. Commun. 2020, 11, 2071. [CrossRef] [PubMed]

96. Wolfe, K.H.; Shields, D.C. Molecular evidence for an ancient duplication of the entire yeast genome. Nature 1997, 387, 708-713. [CrossRef] [PubMed]

97. Wolfe, K.H. Origin of the Yeast Whole-Genome Duplication. PLoS Biol. 2015, 13, e1002221. [CrossRef] [PubMed]

98. Marcet-Houben, M.; Gabaldón, T. Beyond the Whole-Genome Duplication: Phylogenetic Evidence for an Ancient Interspecies Hybridization in the Baker's Yeast Lineage. PLoS Biol. 2015, 13, e1002220. [CrossRef] [PubMed]

99. Charron, G.; Marsit, S.; Hénault, M.; Martin, H.; Landry, C.R. Spontaneous whole-genome duplication restores fertility in interspecific hybrids. Nat. Commun. 2019, 10, 4126. [CrossRef] [PubMed]

100. Byrne, K.P.; Wolfe, K.H. The Yeast Gene Order Browser: Combining curated homology and syntenic context reveals gene fate in polyploid species. Genome Res. 2005, 15, 1456-1461. [CrossRef] [PubMed]

101. Fares, M.A.; Keane, O.M.; Toft, C.; Carretero-Paulet, L.; Jones, G.W. The roles of whole-genome and small-scale duplications in the functional specialization of Saccharomyces cerevisiae genes. PLoS Genet. 2013, 9, e1003176. [CrossRef]

102. Ohno, S. Gene duplication and the uniqueness of vertebrate genomes circa 1970-1999. Semin Cell Dev. Biol. 1999, 10, 517-522. [CrossRef] [PubMed]

103. Lynch, M.; Conery, J.S. The evolutionary demography of duplicate genes. Genome Evol. 2003, 3, 35-44.

104. Kondrashov, F.A.; Rogozin, I.B.; Wolf, Y.I.; Koonin, E.V. Selection in the evolution of gene duplications. Genome Biol. 2002, 3. [CrossRef] [PubMed]

105. Gibson, T.J.; Spring, J. Genetic redundancy in vertebrates: Polyploidy and persistence of genes encoding multidomain proteins. Trends Genet. 1998, 14, 46-49. [CrossRef]

106. Veitia, R.A. Nonlinear effects in macromolecular assembly and dosage sensitivity. J. Theor. Biol. 2003, 220, 19-25. [CrossRef] [PubMed]

107. Veitia, R.A. A sigmoidal transcriptional response: Cooperativity, synergy and dosage effects. Biol. Rev. 2003, 78, 149-170. [CrossRef]

108. Force, A.; Lynch, M.; Pickett, F.B.; Amores, A.; Yan, Y.L.; Postlethwait, J. Preservation of duplicate genes by complementary, degenerative mutations. Genetics 1999, 151, 1531-1545. [CrossRef]

109. Hughes, A.L. The evolution of functionally novel proteins after gene duplication. Proc. R. Soc. London. Ser. B Biol. Sci. 1994, 256, 119-124. [CrossRef]

110. Bhat, P.J.; Murthy, T. Transcriptional control of the GAL/MEL regulon of yeast Saccharomyces cerevisiae: Mechanism of galactosemediated signal transduction. Mol. Microbiol. 2001, 40, 1059-1066. [CrossRef]

111. Taylor, J.S.; Raes, J. Duplication and divergence: The evolution of new genes and old ideas. Annu. Rev. Genet. 2004, 38, 615-643. [CrossRef] [PubMed] 
112. Pougach, K.; Voet, A.; Kondrashov, F.A.; Voordeckers, K.; Christiaens, J.F.; Baying, B.; Benes, V.; Sakai, R.; Aerts, J.; Zhu, B. Duplication of a promiscuous transcription factor drives the emergence of a new regulatory network. Nat. Commun. 2014, 5, 1-12. [CrossRef]

113. Teichmann, S.A.; Babu, M.M. Gene regulatory network growth by duplication. Nat. Genet. 2004, 36, 492-496. [CrossRef] [PubMed]

114. Voordeckers, K.; Pougach, K.; Verstrepen, K.J. How do regulatory networks evolve and expand throughout evolution? Curr. Opin. Biotechnol. 2015, 34, 180-188. [CrossRef] [PubMed]

115. Mattenberger, F.; Sabater-Muñoz, B.; Toft, C.; Fares, M.A. The Phenotypic Plasticity of Duplicated Genes in Saccharomyces cerevisiae and the Origin of Adaptations. G3 2017, 7, 63-75. [CrossRef]

116. Ha, M.; Kim, E.-D.; Chen, Z.J. Duplicate genes increase expression diversity in closely related species and allopolyploids. Proc. Natl. Acad. Sci. USA 2009, 106, 2295-2300. [CrossRef]

117. Rastogi, S.; Liberles, D.A. Subfunctionalization of duplicated genes as a transition state to neofunctionalization. BMC Evol. Biol. 2005, 5, 28. [CrossRef] [PubMed]

118. Van de Peer, Y.; Mizrachi, E.; Marchal, K. The evolutionary significance of polyploidy. Nat. Rev. Genet. 2017, 18, 411-424. [CrossRef]

119. Soltis, P.S.; Marchant, D.B.; van de Peer, Y.; Soltis, D.E. Polyploidy and genome evolution in plants. Curr. Opin. Genet. Dev. 2015, 35, 119-125. [CrossRef]

120. Arrigo, N.; Barker, M.S. Rarely successful polyploids and their legacy in plant genomes. Curr. Opin. Plant Biol. 2012, 15, 140-146. [CrossRef] [PubMed]

121. Mable, B.; Alexandrou, M.; Taylor, M. Genome duplication in amphibians and fish: An extended synthesis. J. Zool. 2011, 284, 151-182. [CrossRef]

122. Otto, S.P.; Whitton, J. Polyploid incidence and evolution. Annu. Rev. Genet. 2000, 34, 401-437. [CrossRef]

123. Meyers, L.A.; Levin, D.A. On the abundance of polyploids in flowering plants. Evolution 2006, 60, 1198-1206. [CrossRef] [PubMed]

124. Albertin, W.; Marullo, P. Polyploidy in fungi: Evolution after whole-genome duplication. Proc. Biol. Sci. 2012, 279, 2497-2509. [CrossRef] [PubMed]

125. Van de Peer, Y.; Maere, S.; Meyer, A. The evolutionary significance of ancient genome duplications. Nat. Rev. Genet. 2009, 10, 725-732. [CrossRef] [PubMed]

126. Jaillon, O.; Aury, J.-M.; Brunet, F.; Petit, J.-L.; Stange-Thomann, N.; Mauceli, E.; Bouneau, L.; Fischer, C.; Ozouf-Costaz, C.; Bernot, A. Genome duplication in the teleost fish Tetraodon nigroviridis reveals the early vertebrate proto-karyotype. Nature 2004, 431, 946-957. [CrossRef] [PubMed]

127. Meyer, A.; van de Peer, Y. From 2R to 3R: Evidence for a fish-specific genome duplication (FSGD). Bioessays 2005, 27, 937-945. [CrossRef]

128. Adams, K.L.; Wendel, J.F. Polyploidy and genome evolution in plants. Curr. Opin. Plant Biol. 2005, 8, 135-141. [CrossRef]

129. Tang, H.; Bowers, J.E.; Wang, X.; Ming, R.; Alam, M.; Paterson, A.H. Synteny and collinearity in plant genomes. Science 2008, 320, 486-488. [CrossRef]

130. Boore, J.L. Two rounds of whole genome duplication in the ancestral vertebrate genome. PLoS Biol. 2006, 10, 314.

131. Kellis, M.; Birren, B.W.; Lander, E.S. Proof and evolutionary analysis of ancient genome duplication in the yeast Saccharomyces cerevisiae. Nature 2004, 428, 617-624. [CrossRef] [PubMed]

132. Edgar, B.A.; Orr-Weaver, T.L. Endoreplication cell cycles: More for less. Cell 2001, 105, 297-306. [CrossRef]

133. Harari, Y.; Ram, Y.; Kupiec, M. Frequent ploidy changes in growing yeast cultures. Curr. Genet. 2018, 64, 1001-1004. [CrossRef]

134. Ortiz-Merino, R.A.; Kuanyshev, N.; Braun-Galleani, S.; Byrne, K.P.; Porro, D.; Branduardi, P.; Wolfe, K.H. Evolutionary restoration of fertility in an interspecies hybrid yeast, by whole-genome duplication after a failed mating-type switch. PLoS Biol. 2017, 15, e2002128. [CrossRef]

135. Steensels, J.; Gallone, B.; Verstrepen, K.J. Interspecific hybridization as a driver of fungal evolution and adaptation. Nat. Rev. Microbiol. 2021. [CrossRef] [PubMed]

136. Kosheleva, K.; Desai, M.M. Recombination Alters the Dynamics of Adaptation on Standing Variation in Laboratory Yeast Populations. Mol. Biol. Evol. 2018, 35, 180-201. [CrossRef]

137. Gorter, F.A.; Derks, M.F.L.; van den Heuvel, J.; Aarts, M.G.M.; Zwaan, B.J.; de Ridder, D.; de Visser, J.A.G.M. Genomics of Adaptation Depends on the Rate of Environmental Change in Experimental Yeast Populations. Mol. Biol. Evol. 2017, 34, 2613-2626. [CrossRef] [PubMed]

138. Venkataram, S.; Dunn, B.; Li, Y.; Agarwala, A.; Chang, J.; Ebel, E.R.; Geiler-Samerotte, K.; Herissant, L.; Blundell, J.R.; Levy, S.F.; et al. Development of a Comprehensive Genotype-to-Fitness Map of Adaptation-Driving Mutations in Yeast. Cell 2016, 166, 1585-1596. [CrossRef]

139. Hong, J.; Gresham, D. Molecular Specificity, Convergence and Constraint Shape Adaptive Evolution in Nutrient-Poor Environments. PLoS Genet. 2014, 10, e1004041. [CrossRef]

140. Gerstein, A.C.; Chun, H.-J.E.; Grant, A.; Otto, S.P. Genomic Convergence toward Diploidy in Saccharomyces cerevisiae. PLoS Genet. 2006, 2, e145. [CrossRef] [PubMed]

141. Harari, Y.; Ram, Y.; Rappoport, N.; Hadany, L.; Kupiec, M. Spontaneous Changes in Ploidy Are Common in Yeast. Curr. Biol. 2018, 28, 825-835. [CrossRef] [PubMed] 
142. Ramsey, J.; Schemske, D.W. Pathways, Mechanisms, and Rates of Polyploid Formation in Flowering Plants. Annu. Rev. Ecol. Syst. 1998, 29, 467-501. [CrossRef]

143. Sharp, N.P.; Sandell, L.; James, C.G.; Otto, S.P. The genome-wide rate and spectrum of spontaneous mutations differ between haploid and diploid yeast. Proc. Natl. Acad. Sci. USA 2018, 115, E5046. [CrossRef] [PubMed]

144. Lynch, M.; Sung, W.; Morris, K.; Coffey, N.; Landry, C.R.; Dopman, E.B.; Dickinson, W.J.; Okamoto, K.; Kulkarni, S.; Hartl, D.L.; et al. A genome-wide view of the spectrum of spontaneous mutations in yeast. Proc. Natl. Acad. Sci. USA 2008, 105, 9272-9277. [CrossRef]

145. Nishant, K.T.; Wei, W.; Mancera, E.; Argueso, J.L.; Schlattl, A.; Delhomme, N.; Ma, X.; Bustamante, C.D.; Korbel, J.O.; Gu, Z.; et al. The Baker's Yeast Diploid Genome Is Remarkably Stable in Vegetative Growth and Meiosis. PLoS Genet. 2010, 6, e1001109. [CrossRef] [PubMed]

146. Zhu, Y.O.; Siegal, M.L.; Hall, D.W.; Petrov, D.A. Precise estimates of mutation rate and spectrum in yeast. Proc. Natl. Acad. Sci. USA 2014, 111, E2310-E2318. [CrossRef] [PubMed]

147. Dutta, A.; Lin, G.; Pankajam, A.V.; Chakraborty, P.; Bhat, N.; Steinmetz, L.M.; Nishant, K.T. Genome Dynamics of Hybrid Saccharomyces cerevisiae During Vegetative and Meiotic Divisions. G3 2017, 7, 3669-3679. [CrossRef] [PubMed]

148. Peter, J.; de Chiara, M.; Friedrich, A.; Yue, J.X.; Pflieger, D.; Bergström, A.; Sigwalt, A.; Barre, B.; Freel, K.; Llored, A.; et al. Genome evolution across 1011 Saccharomyces cerevisiae isolates. Nature 2018, 556, 339-344. [CrossRef]

149. Epstein, C.J. Cell size, nuclear content, and the development of polyploidy in the mammalian liver. Proc. Natl. Acad. Sci. USA 1967, 57, 327. [CrossRef]

150. Gregory, T.R. Coincidence, coevolution, or causation? DNA content, cellsize, and the C-value enigma. Biol. Rev. 2001, 76, 65-101. [CrossRef]

151. Beaulieu, J.M.; Leitch, I.J.; Patel, S.; Pendharkar, A.; Knight, C.A. Genome size is a strong predictor of cell size and stomatal density in angiosperms. New Phytol. 2008, 179, 975-986. [CrossRef]

152. Marad, D.A.; Buskirk, S.W.; Lang, G.I. Altered access to beneficial mutations slows adaptation and biases fixed mutations in diploids. Nat. Ecol. Evol. 2018, 2, 882-889. [CrossRef] [PubMed]

153. Zhang, H.; Zeidler, A.F.B.; Song, W.; Puccia, C.M.; Malc, E.; Greenwell, P.W.; Mieczkowski, P.A.; Petes, T.D.; Argueso, J.L. Gene Copy-Number Variation in Haploid and Diploid Strains of the Yeast Saccharomyces cerevisiae. Genetics 2013, 193, 785. [CrossRef]

154. Deutschbauer, A.M.; Jaramillo, D.F.; Proctor, M.; Kumm, J.; Hillenmeyer, M.E.; Davis, R.W.; Nislow, C.; Giaever, G. Mechanisms of haploinsufficiency revealed by genome-wide profiling in yeast. Genetics 2005, 169, 1915-1925. [CrossRef] [PubMed]

155. Selmecki, A.; Forche, A.; Berman, J. Aneuploidy and isochromosome formation in drug-resistant Candida albicans. Science 2006, 313, 367-370. [CrossRef]

156. Ni, M.; Feretzaki, M.; Li, W.; Floyd-Averette, A.; Mieczkowski, P.; Dietrich, F.S.; Heitman, J. Unisexual and Heterosexual Meiotic Reproduction Generate Aneuploidy and Phenotypic Diversity De Novo in the Yeast Cryptococcus neoformans. PLoS Biol. 2013, 11, e1001653. [CrossRef] [PubMed]

157. Bennett, R.J.; Forche, A.; Berman, J. Rapid mechanisms for generating genome diversity: Whole ploidy shifts, aneuploidy, and loss of heterozygosity. Cold Spring Harb. Perspect. Med. 2014, 4, a019604. [CrossRef] [PubMed]

158. Lu, Y.-J.; Swamy, K.B.S.; Leu, J.-Y. Experimental Evolution Reveals Interplay between Sch9 and Polyploid Stability in Yeast. PLoS Genet. 2016, 12, e1006409. [CrossRef]

159. Storchová, Z.; Breneman, A.; Cande, J.; Dunn, J.; Burbank, K.; O’Toole, E.; Pellman, D. Genome-wide genetic analysis of polyploidy in yeast. Nature 2006, 443, 541-547. [CrossRef]

160. Storchova, Z. Ploidy changes and genome stability in yeast. Yeast 2014, 31, 421-430. [CrossRef] [PubMed]

161. Andalis, A.A.; Storchova, Z.; Styles, C.; Galitski, T.; Pellman, D.; Fink, G.R. Defects arising from whole-genome duplications in Saccharomyces cerevisiae. Genetics 2004, 167, 1109-1121. [CrossRef]

162. Mayer, V.W.; Goin, C.J.; Arras, C.A.; Taylor-Mayer, R.E. Comparison of chemically induced chromosome loss in a diploid, triploid, and tetraploid strain of Saccharomyces cerevisiae. Mutat. Res. Genet. Toxicol. 1992, 279, 41-48. [CrossRef]

163. Mayer, V.W.; Aguilera, A. High levels of chromosome instability in polyploids of Saccharomyces cerevisiae. Mutat. Res. Fundam. Mol. Mech. Mutagenes. 1990, 231, 177-186. [CrossRef]

164. Mortimer, R.K. Radiobiological and genetic studies on a polyploid series (haploid to hexaploid) of Saccharomyces cerevisiae. Radiat. Res. 1958, 9, 312-326. [CrossRef]

165. Scott, A.L.; Richmond, P.A.; Dowell, R.D.; Selmecki, A.M. The Influence of Polyploidy on the Evolution of Yeast Grown in a Sub-Optimal Carbon Source. Mol. Biol. Evol. 2017, 34, 2690-2703. [CrossRef] [PubMed]

166. Thorpe, P.H.; González-Barrera, S.; Rothstein, R. More is not always better: The genetic constraints of polyploidy. Trends Genet. 2007, 23, 263-266. [CrossRef]

167. Torres, E.M.; Sokolsky, T.; Tucker, C.M.; Chan, L.Y.; Boselli, M.; Dunham, M.J.; Amon, A. Effects of aneuploidy on cellular physiology and cell division in haploid yeast. Science 2007, 317, 916-924. [CrossRef]

168. Sheltzer, J.M.; Blank, H.M.; Pfau, S.J.; Tange, Y.; George, B.M.; Humpton, T.J.; Brito, I.L.; Hiraoka, Y.; Niwa, O.; Amon, A. Aneuploidy drives genomic instability in yeast. Science 2011, 333, 1026-1030. [CrossRef]

169. Oromendia, A.B.; Dodgson, S.E.; Amon, A. Aneuploidy causes proteotoxic stress in yeast. Genes Dev. 2012, $26,2696-2708$. [CrossRef] 
170. Zhu, J.; Pavelka, N.; Bradford, W.D.; Rancati, G.; Li, R. Karyotypic determinants of chromosome instability in aneuploid budding yeast. PLoS Genet. 2012, 8, e1002719. [CrossRef] [PubMed]

171. Oromendia, A.B.; Amon, A. Aneuploidy: Implications for protein homeostasis and disease. Dis. Model. Mech. 2014, 7, 15-20. [CrossRef] [PubMed]

172. Donnelly, N.; Storchova, Z. Causes and consequences of protein folding stress in aneuploid cells. Cell Cycle 2015, 14, 495-501. [CrossRef] [PubMed]

173. Passerini, V.; Ozeri-Galai, E.; de Pagter, M.S.; Donnelly, N.; Schmalbrock, S.; Kloosterman, W.P.; Kerem, B.; Storchova, Z. The presence of extra chromosomes leads to genomic instability. Nat. Commun. 2016, 7, 10754. [CrossRef]

174. Ravichandran, M.C.; Fink, S.; Clarke, M.N.; Hofer, F.C.; Campbell, C.S. Genetic interactions between specific chromosome copy number alterations dictate complex aneuploidy patterns. Genes Dev. 2018, 32, 1485-1498. [CrossRef]

175. Tsai, H.-J.; Nelliat, A.R.; Choudhury, M.I.; Kucharavy, A.; Bradford, W.D.; Cook, M.E.; Kim, J.; Mair, D.B.; Sun, S.X.; Schatz, M.C.; et al. Hypo-osmotic-like stress underlies general cellular defects of aneuploidy. Nature 2019, 570, 117-121. [CrossRef] [PubMed]

176. Torres, E.M.; Dephoure, N.; Panneerselvam, A.; Tucker, C.M.; Whittaker, C.A.; Gygi, S.P.; Dunham, M.J.; Amon, A. Identification of aneuploidy-tolerating mutations. Cell 2010, 143, 71-83. [CrossRef]

177. Sheltzer, J.M.; Torres, E.M.; Dunham, M.J.; Amon, A. Transcriptional consequences of aneuploidy. Proc. Natl. Acad. Sci. USA 2012, 109, 12644-12649. [CrossRef] [PubMed]

178. Thorburn, R.R.; Gonzalez, C.; Brar, G.A.; Christen, S.; Carlile, T.M.; Ingolia, N.T.; Sauer, U.; Weissman, J.S.; Amon, A. Aneuploid yeast strains exhibit defects in cell growth and passage through START. Mol. Biol. Cell 2013, 24, 1274-1289. [CrossRef]

179. Dephoure, N.; Hwang, S.; O'Sullivan, C.; Dodgson, S.E.; Gygi, S.P.; Amon, A.; Torres, E.M. Quantitative proteomic analysis reveals posttranslational responses to aneuploidy in yeast. eLife 2014, 3, e03023. [CrossRef]

180. Dodgson, S.E.; Santaguida, S.; Kim, S.; Sheltzer, J.; Amon, A. The pleiotropic deubiquitinase Ubp3 confers aneuploidy tolerance. Genes Dev. 2016, 30, 2259-2271. [CrossRef] [PubMed]

181. Brennan, C.M.; Vaites, L.P.; Wells, J.N.; Santaguida, S.; Paulo, J.A.; Storchova, Z.; Harper, J.W.; Marsh, J.A.; Amon, A. Protein aggregation mediates stoichiometry of protein complexes in aneuploid cells. Genes Dev. 2019, 33, 1031-1047. [CrossRef]

182. Hose, J.; Yong, C.M.; Sardi, M.; Wang, Z.; Newton, M.A.; Gasch, A.P. Dosage compensation can buffer copy-number variation in wild yeast. eLife 2015, 4, e05462. [CrossRef] [PubMed]

183. Strope, P.K.; Skelly, D.A.; Kozmin, S.G.; Mahadevan, G.; Stone, E.A.; Magwene, P.M.; Dietrich, F.S.; McCusker, J.H. The 100genomes strains, an S. cerevisiae resource that illuminates its natural phenotypic and genotypic variation and emergence as an opportunistic pathogen. Genome Res. 2015, 25, 762-774. [CrossRef]

184. Van den Broek, M.; Bolat, I.; Nijkamp, J.; Ramos, E.; Luttik, M.A.; Koopman, F.; Geertman, J.; de Ridder, D.; Pronk, J.T.; Daran, J.-M. Chromosomal copy number variation in Saccharomyces pastorianus is evidence for extensive genome dynamics in industrial lager brewing strains. Appl. Environ. Microbiol. 2015, 81, 6253-6267. [CrossRef]

185. Zhu, Y.O.; Sherlock, G.; Petrov, D.A. Whole Genome Analysis of 132 Clinical Saccharomyces cerevisiae Strains Reveals Extensive Ploidy Variation. G3 2016, 6, 2421-2434. [CrossRef] [PubMed]

186. Gorter de Vries, A.R.; Pronk, J.T.; Daran, J.-M.G. Industrial Relevance of Chromosomal Copy Number Variation in Saccharomyces Yeasts. Appl. Environ. Microbiol. 2017, 83, e03206-16. [CrossRef] [PubMed]

187. Duan, S.F.; Han, P.J.; Wang, Q.M.; Liu, W.Q.; Shi, J.Y.; Li, K.; Zhang, X.L.; Bai, F.Y. The origin and adaptive evolution of domesticated populations of yeast from Far East Asia. Nat. Commun. 2018, 9, 2690. [CrossRef] [PubMed]

188. Fay, J.C.; Liu, P.; Ong, G.T.; Dunham, M.J.; Cromie, G.A.; Jeffery, E.W.; Ludlow, C.L.; Dudley, A.M. A polyploid admixed origin of beer yeasts derived from European and Asian wine populations. PLoS Biol. 2019, 17, e3000147. [CrossRef]

189. Gallone, B.; Steensels, J.; Mertens, S.; Dzialo, M.C.; Gordon, J.L.; Wauters, R.; Thesseling, F.A.; Bellinazzo, F.; Saels, V.; Herrera-Malaver, B.; et al. Interspecific hybridization facilitates niche adaptation in beer yeast. Nat. Ecol. Evol. 2019, 3, 1562-1575. [CrossRef] [PubMed]

190. Gasch, A.P.; Hose, J.; Newton, M.A.; Sardi, M.; Yong, M.; Wang, Z. Further support for aneuploidy tolerance in wild yeast and effects of dosage compensation on gene copy-number evolution. eLife 2016, 5, e14409. [CrossRef] [PubMed]

191. Hose, J.; Escalante, L.E.; Clowers, K.J.; Dutcher, H.A.; Robinson, D.; Bouriakov, V.; Coon, J.J.; Shishkova, E.; Gasch, A.P. The genetic basis of aneuploidy tolerance in wild yeast. eLife 2020, 9. [CrossRef]

192. Larrimore, K.E.; Barattin-Voynova, N.S.; Reid, D.W.; Ng, D.T.W. Aneuploidy-induced proteotoxic stress can be effectively tolerated without dosage compensation, genetic mutations, or stress responses. BMC Biol. 2020, 18, 117. [CrossRef] [PubMed]

193. Scopel, E.F.C.; Hose, J.; Bensasson, D.; Gasch, A.P. Genetic variation in aneuploidy prevalence and tolerance across the Saccharomyces cerevisiae phylogeny. bioRxiv 2020. [CrossRef]

194. Chen, G.; Bradford, W.D.; Seidel, C.W.; Li, R. Hsp90 stress potentiates rapid cellular adaptation through induction of aneuploidy. Nature 2012, 482, 246-250. [CrossRef]

195. Yona, A.H.; Manor, Y.S.; Herbst, R.H.; Romano, G.H.; Mitchell, A.; Kupiec, M.; Pilpel, Y.; Dahan, O. Chromosomal duplication is a transient evolutionary solution to stress. Proc. Natl. Acad. Sci. USA 2012, 109, 21010-21015. [CrossRef]

196. Sunshine, A.B.; Payen, C.; Ong, G.T.; Liachko, I.; Tan, K.M.; Dunham, M.J. The fitness consequences of aneuploidy are driven by condition-dependent gene effects. PLoS Biol. 2015, 13, e1002155. [CrossRef] 
197. Kaya, A.; Gerashchenko, M.V.; Seim, I.; Labarre, J.; Toledano, M.B.; Gladyshev, V.N. Adaptive aneuploidy protects against thiol peroxidase deficiency by increasing respiration via key mitochondrial proteins. Proc. Natl. Acad. Sci. USA 2015, 112, 10685-10690. [CrossRef]

198. Linder, R.A.; Greco, J.P.; Seidl, F.; Matsui, T.; Ehrenreich, I.M. The stress-inducible peroxidase TSA2 underlies a conditionally beneficial chromosomal duplication in Saccharomyces cerevisiae. G3 Genes Genomes Genet. 2017, 7, 3177-3184. [CrossRef]

199. Beaupere, C.; Dinatto, L.; Wasko, B.M.; Chen, R.B.; VanValkenburg, L.; Kiflezghi, M.G.; Lee, M.B.; Promislow, D.E.L.; Dang, W.; Kaeberlein, M.; et al. Genetic screen identifies adaptive aneuploidy as a key mediator of ER stress resistance in yeast. Proc. Natl. Acad. Sci. USA 2018, 115, 9586-9591. [CrossRef] [PubMed]

200. Yang, F.; Teoh, F.; Tan, A.S.M.; Cao, Y.; Pavelka, N.; Berman, J. Aneuploidy Enables Cross-Adaptation to Unrelated Drugs. Mol. Biol. Evol. 2019, 36, 1768-1782. [CrossRef]

201. Todd, R.T.; Selmecki, A. Expandable and reversible copy number amplification drives rapid adaptation to antifungal drugs. eLife 2020, 9. [CrossRef]

202. Millet, C.; Ausiannikava, D.; Le Bihan, T.; Granneman, S.; Makovets, S. Cell populations can use aneuploidy to survive telomerase insufficiency. Nat. Commun. 2015, 6, 8664. [CrossRef] [PubMed]

203. Millet, C.; Makovets, S. Aneuploidy as a mechanism of adaptation to telomerase insufficiency. Curr. Genet. 2016, 62, 557-564. [CrossRef]

204. Liu, G.; Yong, M.Y.J.; Yurieva, M.; Srinivasan, K.G.; Liu, J.; Lim, J.S.Y.; Poidinger, M.; Wright, G.D.; Zolezzi, F.; Choi, H. Gene essentiality is a quantitative property linked to cellular evolvability. Cell 2015, 163, 1388-1399. [CrossRef]

205. Ryu, H.Y.; Wilson, N.R.; Mehta, S.; Hwang, S.S.; Hochstrasser, M. Loss of the SUMO protease Ulp2 triggers a specific multichromosome aneuploidy. Genes Dev. 2016, 30, 1881-1894. [CrossRef]

206. Hughes, T.R.; Roberts, C.J.; Dai, H.; Jones, A.R.; Meyer, M.R.; Slade, D.; Burchard, J.; Dow, S.; Ward, T.R.; Kidd, M.J.; et al. Widespread aneuploidy revealed by DNA microarray expression profiling. Nat. Genet. 2000, 25, 333-337. [CrossRef]

207. Pankajam, A.V.; Dash, S.; Saifudeen, A.; Dutta, A.; Nishant, K.T. Loss of Heterozygosity and Base Mutation Rates Vary among Saccharomyces cerevisiae Hybrid Strains. G3 Genes Genomes Genet. 2020, 10, 3309. [CrossRef]

208. Tsai, H.J.; Nelliat, A. A Double-Edged Sword: Aneuploidy is a Prevalent Strategy in Fungal Adaptation. Genes 2019, $10,787$. [CrossRef]

209. Berman, J. Ploidy plasticity: A rapid and reversible strategy for adaptation to stress. FEMS Yeast Res. 2016, 16, fow020. [CrossRef] [PubMed]

210. Chen, G.; Rubinstein, B.; Li, R. Whole chromosome aneuploidy: Big mutations drive adaptation by phenotypic leap. Bioessays 2012, 34, 893-900. [CrossRef]

211. Liebman, S.; Shalit, P.; Picologlou, S. Ty elements are involved in the formation of deletions in DEL1 strains of Saccharomyces cerevisiae. Cell 1981, 26, 401-409. [CrossRef]

212. Rothstein, R.; Helms, C.; Rosenberg, N. Concerted deletions and inversions are caused by mitotic recombination between delta sequences in Saccharomyces cerevisiae. Mol. Cell. Biol. 1987, 7, 1198-1207. [CrossRef]

213. Schiestl, R.H. Nonmutagenic carcinogens induce intrachromosomal recombination in yeast. Nature 1989, 337, 285-288. [CrossRef] [PubMed]

214. Dorsey, M.; Peterson, C.; Bray, K.; Paquin, C.E. Spontaneous amplification of the ADH4 gene in Saccharomyces cerevisiae. Genetics 1992, 132, 943-950. [CrossRef]

215. Tourrette, Y.; Schacherer, J.; Fritsch, E.; Potier, S.; Souciet, J.L.; de Montigny, J. Spontaneous deletions and reciprocal translocations in Saccharomyces cerevisiae: Influence of ploidy. Mol. Microbiol. 2007, 64, 382-395. [CrossRef] [PubMed]

216. Pryde, F.E.; Gorham, H.C.; Louis, E.J. Chromosome ends: All the same under their caps. Curr. Opin. Genet. Dev. 1997, 7, 822-828. [CrossRef]

217. Mefford, H.C.; Trask, B.J. The complex structure and dynamic evolution of human subtelomeres. Nat. Rev. Genet. 2002, 3, 91-102. [CrossRef] [PubMed]

218. Eichler, E.E.; Sankoff, D. Structural dynamics of eukaryotic chromosome evolution. Science 2003, 301, 793-797. [CrossRef] [PubMed]

219. Dujon, B. Yeast evolutionary genomics. Nat. Rev. Genet. 2010, 11, 512-524. [CrossRef]

220. Winzeler, E.A.; Castillo-Davis, C.I.; Oshiro, G.; Liang, D.; Richards, D.R.; Zhou, Y.; Hartl, D.L. Genetic diversity in yeast assessed with whole-genome oligonucleotide arrays. Genetics 2003, 163, 79-89. [CrossRef]

221. Brown, C.A.; Murray, A.W.; Verstrepen, K.J. Rapid expansion and functional divergence of subtelomeric gene families in yeasts. Curr. Biol. 2010, 20, 895-903. [CrossRef]

222. Ames, R.M.; Rash, B.M.; Hentges, K.E.; Robertson, D.L.; Delneri, D.; Lovell, S.C. Gene duplication and environmental adaptation within yeast populations. Genome Biol. Evol. 2010, 2, 591-601. [CrossRef] [PubMed]

223. Kirschner, M.; Gerhart, J. Evolvability. Proc. Natl. Acad. Sci. USA 1998, 95, 8420-8427. [CrossRef] [PubMed]

224. Bendixsen, D.P.; Gettle, N.; Gilchrist, C.; Zhang, Z.; Stelkens, R. Genomic evidence of an ancient East Asian divergence event in wild Saccharomyces cerevisiae. Genome Biol. Evol. 2021, 13. [CrossRef]

225. Avelar, A.T.; Perfeito, L.; Gordo, I.; Ferreira, M.G. Genome architecture is a selectable trait that can be maintained by antagonistic pleiotropy. Nat. Commun. 2013, 4, 1-10. [CrossRef] 
226. Gordon, J.L.; Byrne, K.P.; Wolfe, K.H. Mechanisms of chromosome number evolution in yeast. PLoS Genet. 2011, 7, e1002190. [CrossRef] [PubMed]

227. Fraser, J.A.; Huang, J.C.; Pukkila-Worley, R.; Alspaugh, J.A.; Mitchell, T.G.; Heitman, J. Chromosomal Translocation and Segmental Duplication in Cryptococcus neoformans. Eukaryotic Cell 2005, 4, 401. [CrossRef]

228. Bradshaw, R.E.; Sim, A.D.; Chettri, P.; Dupont, P.Y.; Guo, Y.; Hunziker, L.; McDougal, R.L.; van der Nest, A.; Fourie, A.; Wheeler, D. Global population genomics of the forest pathogen Dothistroma septosporum reveal chromosome duplications in high dothistromin-producing strains. Mol. Plant Pathol. 2019, 20, 784-799. [CrossRef] [PubMed]

229. Wang, Q.; Sun, M.; Zhang, Y.; Song, Z.; Zhang, S.; Zhang, Q.; Xu, J.R.; Liu, H. Extensive chromosomal rearrangements and rapid evolution of novel effector superfamilies contribute to host adaptation and speciation in the basal ascomycetous fungi. Mol. Plant Pathol. 2020, 21, 330-348. [CrossRef]

230. Hou, J.; Friedrich, A.; de Montigny, J.; Schacherer, J. Chromosomal rearrangements as a major mechanism in the onset of reproductive isolation in Saccharomyces cerevisiae. Curr. Biol. 2014, 24, 1153-1159. [CrossRef]

231. Noor, M.A.; Grams, K.L.; Bertucci, L.A.; Reiland, J. Chromosomal inversions and the reproductive isolation of species. Proc. Natl. Acad. Sci. USA 2001, 98, 12084-12088. [CrossRef] [PubMed]

232. Rieseberg, L.H. Chromosomal rearrangements and speciation. Trends Ecol. Evol. 2001, 16, 351-358. [CrossRef]

233. Kirkpatrick, M.; Barton, N. Chromosome inversions, local adaptation and speciation. Genetics 2006, 173, 419-434. [CrossRef]

234. Navarro, A.; Barton, N.H. Accumulating postzygotic isolation genes in parapatry: A new twist on chromosomal speciation. Evolution 2003, 57, 447-459. [CrossRef] [PubMed]

235. Seoighe, C.; Federspiel, N.; Jones, T.; Hansen, N.; Bivolarovic, V.; Surzycki, R.; Tamse, R.; Komp, C.; Huizar, L.; Davis, R.W.; et al. Prevalence of small inversions in yeast gene order evolution. Proc. Natl. Acad. Sci. USA 2000, 97, 14433-14437. [CrossRef] [PubMed]

236. Faria, R.; Navarro, A. Chromosomal speciation revisited: Rearranging theory with pieces of evidence. Trends Ecol. Evol. 2010, 25, 660-669. [CrossRef] [PubMed]

237. Puig Giribets, M.; García Guerreiro, M.P.; Santos, M.; Ayala, F.J.; Tarrío, R.; Rodríguez-Trelles, F. Chromosomal inversions promote genomic islands of concerted evolution of Hsp70 genes in the Drosophila subobscura species subgroup. Mol. Ecol. 2019, 28, 1316-1332. [CrossRef] [PubMed]

238. Ayala, D.; Zhang, S.; Chateau, M.; Fouet, C.; Morlais, I.; Costantini, C.; Hahn, M.W.; Besansky, N.J. Association mapping desiccation resistance within chromosomal inversions in the African malaria vector Anopheles gambiae. Mol. Ecol. 2019, 28, 1333-1342. [CrossRef]

239. Colson, I.; Delneri, D.; Oliver, S.G. Effects of reciprocal chromosomal translocations on the fitness of Saccharomyces cerevisiae. EMBO Rep. 2004, 5, 392-398. [CrossRef] [PubMed]

240. Brown, W.R.; Liti, G.; Rosa, C.; James, S.; Roberts, I.; Robert, V.; Jolly, N.; Tang, W.; Baumann, P.; Green, C.; et al. A Geographically Diverse Collection of Schizosaccharomyces pombe Isolates Shows Limited Phenotypic Variation but Extensive Karyotypic Diversity. G3 2011, 1, 615-626. [CrossRef] [PubMed]

241. Naseeb, S.; Carter, Z.; Minnis, D.; Donaldson, I.; Zeef, L.; Delneri, D. Widespread Impact of Chromosomal Inversions on Gene Expression Uncovers Robustness via Phenotypic Buffering. Mol. Biol. Evol. 2016, 33, 1679-1696. [CrossRef]

242. Thomson, J.M.; Gaucher, E.A.; Burgan, M.F.; de Kee, D.W.; Li, T.; Aris, J.P.; Benner, S.A. Resurrecting ancestral alcohol dehydrogenases from yeast. Nat. Genet. 2005, 37, 630-635. [CrossRef] [PubMed]

243. Piškur, J.; Rozpędowska, E.; Polakova, S.; Merico, A.; Compagno, C. How did Saccharomyces evolve to become a good brewer? Trends Genet. 2006, 22, 183-186. [CrossRef]

244. Conant, G.C.; Wolfe, K.H. Increased glycolytic flux as an outcome of whole-genome duplication in yeast. Mol. Syst. Biol. 2007, 3, 129. [CrossRef] [PubMed]

245. Van Hoek, M.J.; Hogeweg, P. Metabolic adaptation after whole genome duplication. Mol. Biol. Evol. 2009, 26, $2441-2453$. [CrossRef] [PubMed]

246. Brown, C.J.; Todd, K.M.; Rosenzweig, R.F. Multiple duplications of yeast hexose transport genes in response to selection in a glucose-limited environment. Mol. Biol. Evol. 1998, 15, 931-942. [CrossRef]

247. Lauer, S.; Avecilla, G.; Spealman, P.; Sethia, G.; Brandt, N.; Levy, S.F.; Gresham, D. Single-cell copy number variant detection reveals the dynamics and diversity of adaptation. PLoS Biol. 2018, 16, e3000069. [CrossRef]

248. Nikitin, D.; Tosato, V.; Zavec, A.B.; Bruschi, C.V. Cellular and molecular effects of nonreciprocal chromosome translocations in Saccharomyces cerevisiae. Proc. Natl. Acad. Sci. USA 2008, 105, 9703-9708. [CrossRef]

249. Janbon, G.; Sherman, F.; Rustchenko, E. Monosomy of a specific chromosome determines sorbose utilization: A novel regulatory mechanism in Candida albicans. Proc. Natl. Acad. Sci. USA 1998, 95, 5150. [CrossRef]

250. Ezov, T.K.; Boger-Nadjar, E.; Frenkel, Z.E.; Katsperovski, I.; Kemeny, S.; Nevo, E.; Korol, A.; Kashi, Y. Molecular-genetic biodiversity in a natural population of the yeast Saccharomyces cerevisiae from "Evolution Canyon": Microsatellite polymorphism, ploidy and controversial sexual status. Genetics 2006, 174, 1455-1468. [CrossRef] [PubMed]

251. Chang, S.-L.; Lai, H.-Y.; Tung, S.-Y.; Leu, J.-Y. Dynamic large-scale chromosomal rearrangements fuel rapid adaptation in yeast populations. PLoS Genet. 2013, 9, e1003232. [CrossRef]

252. Gerstein, A.C.; Ono, J.; Lo, D.S.; Campbell, M.L.; Kuzmin, A.; Otto, S.P. Too much of a good thing: The unique and repeated paths toward copper adaptation. Genetics 2015, 199, 555-571. [CrossRef] 
253. Will, J.L.; Kim, H.S.; Clarke, J.; Painter, J.C.; Fay, J.C.; Gasch, A.P. Incipient balancing selection through adaptive loss of aquaporins in natural Saccharomyces cerevisiae populations. PLoS Genet. 2010, 6, e1000893. [CrossRef] [PubMed]

254. Huang, C.-J.; Lu, M.-Y.; Chang, Y.-W.; Li, W.-H. Experimental Evolution of Yeast for High-Temperature Tolerance. Mol. Biol. Evol. 2018, 35, 1823-1839. [CrossRef]

255. Caspeta, L.; Chen, Y.; Ghiaci, P.; Feizi, A.; Buskov, S.; Hallström, B.M.; Petranovic, D.; Nielsen, J. Altered sterol composition renders yeast thermotolerant. Science 2014, 346, 75-78. [CrossRef] [PubMed]

256. Morard, M.; Macías, L.G.; Adam, A.C.; Lairón-Peris, M.; Pérez-Torrado, R.; Toft, C.; Barrio, E. Aneuploidy and Ethanol Tolerance in Saccharomyces cerevisiae. Front. Genet. 2019, 10, 82. [CrossRef] [PubMed]

257. Goto-Yamamoto, N.; Kitano, K.; Shiki, K.; Yoshida, Y.; Suzuki, T.; Iwata, T.; Yamane, Y.; Hara, S. SSU1-R, a sulfite resistance gene of wine yeast, is an allele of SSU1 with a different upstream sequence. J. Ferment. Bioeng. 1998, 86, 427-433. [CrossRef]

258. Pérez-Ortın, J.E.; Querol, A.; Puig, S.; Barrio, E. Molecular characterization of a chromosomal rearrangement involved in the adaptive evolution of yeast strains. Genome Res. 2002, 12, 1533-1539. [CrossRef]

259. Yuasa, N.; Nakagawa, Y.; Hayakawa, M.; Iimura, Y. Distribution of the sulfite resistance gene SSU1-R and the variation in its promoter region in wine yeasts. J. Biosc. Bioeng. 2004, 98, 394-397. [CrossRef]

260. Zimmer, A.; Durand, C.; Loira, N.; Durrens, P.; Sherman, D.J.; Marullo, P. QTL dissection of lag phase in wine fermentation reveals a new translocation responsible for Saccharomyces cerevisiae adaptation to sulfite. PLoS ONE 2014, 9, e86298. [CrossRef]

261. García-Ríos, E.; Nuévalos, M.; Barrio, E.; Puig, S.; Guillamón, J.M. A new chromosomal rearrangement improves the adaptation of wine yeasts to sulfite. Environ. Microbiol. 2019, 21, 1771-1781. [CrossRef]

262. Selmecki, A.; Gerami-Nejad, M.; Paulson, C.; Forche, A.; Berman, J. An isochromosome confers drug resistance in vivo by amplification of two genes, ERG11 and TAC1. Mol. Microbiol. 2008, 68, 624-641. [CrossRef] [PubMed]

263. Sionov, E.; Lee, H.; Chang, Y.C.; Kwon-Chung, K.J. Cryptococcus neoformans overcomes stress of azole drugs by formation of disomy in specific multiple chromosomes. PLoS Pathog. 2010, 6, e1000848. [CrossRef] [PubMed]

264. Sionov, E.; Chang, Y.C.; Kwon-Chung, K.J. Azole heteroresistance in Cryptococcus neoformans: Emergence of resistant clones with chromosomal disomy in the mouse brain during fluconazole treatment. Antimicrob. Agents Chemother. 2013, 57, 5127-5130. [CrossRef]

265. Ngamskulrungroj, P.; Chang, Y.; Hansen, B.; Bugge, C.; Fischer, E.; Kwon-Chung, K.J. Characterization of the chromosome 4 genes that affect fluconazole-induced disomy formation in Cryptococcus neoformans. PLoS ONE 2012, 7, e33022. [CrossRef]

266. Ford, C.B.; Funt, J.M.; Abbey, D.; Issi, L.; Guiducci, C.; Martinez, D.A.; Delorey, T.; Li, B.y.; White, T.C.; Cuomo, C.; et al. The evolution of drug resistance in clinical isolates of Candida albicans. eLife 2015, 4, e00662. [CrossRef]

267. Yang, F.; Kravets, A.; Bethlendy, G.; Welle, S.; Rustchenko, E. Chromosome 5 monosomy of Candida albicans controls susceptibility to various toxic agents, including major antifungals. Antimicrob. Agents Chemother. 2013, 57, 5026-5036. [CrossRef] [PubMed]

268. Osherov, N.; Kontoyiannis, D.P.; Romans, A.; May, G.S. Resistance to itraconazole in Aspergillus nidulans and Aspergillus fumigatus is conferred by extra copies of the A. nidulans P-450 14 $\alpha$-demethylase gene, pdmA. J. Antimicrob. Chemother. 2001, 48, 75-81. [CrossRef]

269. Jones, L.; Riaz, S.; Morales-Cruz, A.; Amrine, K.C.; McGuire, B.; Gubler, W.D.; Walker, M.A.; Cantu, D. Adaptive genomic structural variation in the grape powdery mildew pathogen, Erysiphe necator. BMC Genom. 2014, 15, 1-18. [CrossRef] [PubMed]

270. Forche, A.; Solis, N.V.; Swidergall, M.; Thomas, R.; Guyer, A.; Beach, A.; Cromie, G.A.; Le, G.T.; Lowell, E.; Pavelka, N. Selection of Candida albicans trisomy during oropharyngeal infection results in a commensal-like phenotype. PLoS Genet. 2019, 15, e1008137. [CrossRef]

271. Gonçalves, M.; Pontes, A.; Almeida, P.; Barbosa, R.; Serra, M.; Libkind, D.; Hutzler, M.; Gonçalves, P.; Sampaio, J.P. Distinct Domestication Trajectories in Top-Fermenting Beer Yeasts and Wine Yeasts. Curr. Biol. 2016, 26, 2750-2761. [CrossRef]

272. Hope, E.A.; Amorosi, C.J.; Miller, A.W.; Dang, K.; Heil, C.S.; Dunham, M.J. Experimental evolution reveals favored adaptive routes to cell aggregation in yeast. Genetics 2017, 206, 1153-1167. [CrossRef]

273. Hunter, A.J.; Jin, B.; Kelly, J.M. Independent duplications of $\alpha$-amylase in different strains of Aspergillus oryzae. Fungal Genet. Biol. 2011, 48, 438-444. [CrossRef]

274. Gibbons, J.G.; Salichos, L.; Slot, J.C.; Rinker, D.C.; McGary, K.L.; King, J.G.; Klich, M.A.; Tabb, D.L.; McDonald, W.H.; Rokas, A. The evolutionary imprint of domestication on genome variation and function of the filamentous fungus Aspergillus oryzae. Curr. Biol. 2012, 22, 1403-1409. [CrossRef]

275. Sato, T.K.; Liu, T.; Parreiras, L.S.; Williams, D.L.; Wohlbach, D.J.; Bice, B.D.; Ong, I.M.; Breuer, R.J.; Qin, L.; Busalacchi, D.; et al. Harnessing genetic diversity in Saccharomyces cerevisiae for fermentation of xylose in hydrolysates of alkaline hydrogen peroxide-pretreated biomass. Appl. Environ. Microbiol. 2014, 80, 540-554. [CrossRef]

276. Gasch, A.P.; Huang, M.; Metzner, S.; Botstein, D.; Elledge, S.J.; Brown, P.O. Genomic expression responses to DNA-damaging agents and the regulatory role of the yeast ATR homolog Mec1p. Mol. Biol. Cell 2001, 12, 2987-3003. [CrossRef]

277. De Kok, S.; Nijkamp, J.F.; Oud, B.; Roque, F.C.; de Ridder, D.; Daran, J.-M.; Pronk, J.T.; van Maris, A.J. Laboratory evolution of new lactate transporter genes in a jen $1 \Delta$ mutant of Saccharomyces cerevisiae and their identification as ADY2 alleles by whole-genome resequencing and transcriptome analysis. FEMS Yeast Res. 2012, 12, 359-374. [CrossRef] [PubMed]

278. Sirr, A.; Cromie, G.A.; Jeffery, E.W.; Gilbert, T.L.; Ludlow, C.L.; Scott, A.C.; Dudley, A.M. Allelic variation, aneuploidy, and nongenetic mechanisms suppress a monogenic trait in yeast. Genetics 2015, 199, 247-262. [CrossRef] [PubMed] 
279. Mount, H.O.C.; Revie, N.M.; Todd, R.T.; Anstett, K.; Collins, C.; Costanzo, M.; Boone, C.; Robbins, N.; Selmecki, A.; Cowen, L.E. Global analysis of genetic circuitry and adaptive mechanisms enabling resistance to the azole antifungal drugs. PLoS Genet. 2018, 14, e1007319. [CrossRef] [PubMed]

280. Haugen, A.C.; Kelley, R.; Collins, J.B.; Tucker, C.J.; Deng, C.; Afshari, C.A.; Brown, J.M.; Ideker, T.; van Houten, B. Integrating phenotypic and expression profiles to map arsenic-response networks. Genome Biol. 2004, 5, R95. [CrossRef]

281. Dunn, B.; Levine, R.P.; Sherlock, G. Microarray karyotyping of commercial wine yeast strains reveals shared, as well as unique, genomic signatures. BMC Genom. 2005, 6, 1-21. [CrossRef] [PubMed]

282. Carreto, L.; Eiriz, M.F.; Gomes, A.C.; Pereira, P.M.; Schuller, D.; Santos, M.A. Comparative genomics of wild type yeast strains unveils important genome diversity. BMC Genom. 2008, 9, 1-17. [CrossRef] [PubMed]

283. Naseeb, S.; Delneri, D. Impact of Chromosomal Inversions on the Yeast DAL Cluster. PLoS ONE 2012, 7, e42022. [CrossRef] [PubMed]

284. Naumov, G.I.; James, S.A.; Naumova, E.S.; Louis, E.J.; Roberts, I.N. Three new species in the Saccharomyces sensu stricto complex: Saccharomyces cariocanus, Saccharomyces kudriavzevii and Saccharomyces mikatae. Int. J. Syst. Evol. Microbiol. 2000, 50, 1931-1942. [CrossRef] [PubMed]

285. Dymond, J.S.; Richardson, S.M.; Coombes, C.E.; Babatz, T.; Muller, H.; Annaluru, N.; Blake, W.J.; Schwerzmann, J.W.; Dai, J.; Lindstrom, D.L. Synthetic chromosome arms function in yeast and generate phenotypic diversity by design. Nature 2011, 477, 471-476. [CrossRef] [PubMed]

286. Ma, L.; Li, Y.; Chen, X.; Ding, M.; Wu, Y.; Yuan, Y.-J. SCRaMbLE generates evolved yeasts with increased alkali tolerance. Microb. Cell Factories 2019, 18,1-11. [CrossRef] [PubMed]

287. Liu, W.; Luo, Z.; Wang, Y.; Pham, N.T.; Tuck, L.; Pérez-Pi, I.; Liu, L.; Shen, Y.; French, C.; Auer, M. Rapid pathway prototyping and engineering using in vitro and in vivo synthetic genome SCRaMbLE-in methods. Nat. Commun. 2018, 9, 1936. [CrossRef]

288. Luo, Z.; Wang, L.; Wang, Y.; Zhang, W.; Guo, Y.; Shen, Y.; Jiang, L.; Wu, Q.; Zhang, C.; Cai, Y. Identifying and characterizing SCRaMbLEd synthetic yeast using ReSCuES. Nat. Commun. 2018, 9, 1930. [CrossRef]

289. Blount, B.; Gowers, G.F.; Ho, J.; Ledesma-Amaro, R.; Jovicevic, D.; McKiernan, R.; Xie, Z.; Li, B.; Yuan, Y.; Ellis, T. Rapid host strain improvement by in vivo rearrangement of a synthetic yeast chromosome. Nat. Commun. 2018, 9, 1932. [CrossRef]

290. Wang, J.; Xie, Z.-X.; Ma, Y.; Chen, X.-R.; Huang, Y.-Q.; He, B.; Jia, B.; Li, B.-Z.; Yuan, Y.-J. Ring synthetic chromosome V SCRaMbLE. Nat. Commun. 2018, 9, 3783. [CrossRef]

291. Jia, B.; Wu, Y.; Li, B.-Z.; Mitchell, L.A.; Liu, H.; Pan, S.; Wang, J.; Zhang, H.-R.; Jia, N.; Li, B. Precise control of SCRaMbLE in synthetic haploid and diploid yeast. Nat. Commun. 2018, 9, 1933. [CrossRef]

292. Wu, Y.; Zhu, R.-Y.; Mitchell, L.A.; Ma, L.; Liu, R.; Zhao, M.; Jia, B.; Xu, H.; Li, Y.-X.; Yang, Z.-M. In vitro DNA SCRaMbLE. Nat. Commun. 2018, 9, 1935. [CrossRef] [PubMed]

293. Gowers, G.O.F.; Chee, S.M.; Bell, D.; Suckling, L.; Kern, M.; Tew, D.; McClymont, D.W.; Ellis, T. Improved betulinic acid biosynthesis using synthetic yeast chromosome recombination and semi-automated rapid LC-MS screening. Nat. Commun. 2020, 11, 868. [CrossRef] [PubMed]

294. Bansal, V.; Boucher, C. Sequencing Technologies and Analyses: Where Have We Been and Where Are We Going? iScience 2019, 18, 37-41. [CrossRef] [PubMed] 